Portland State University

PDXScholar

\title{
A Comparison of Education Systems in Nigeria and the United States of America
}

James Edem Etim

Portland State University

Follow this and additional works at: https://pdxscholar.library.pdx.edu/open_access_etds

Part of the Bilingual, Multilingual, and Multicultural Education Commons, and the Educational Assessment, Evaluation, and Research Commons

Let us know how access to this document benefits you.

\section{Recommended Citation}

Etim, James Edem, "A Comparison of Education Systems in Nigeria and the United States of America" (1976). Dissertations and Theses. Paper 2275.

https://doi.org/10.15760/etd.2272

This Thesis is brought to you for free and open access. It has been accepted for inclusion in Dissertations and Theses by an authorized administrator of PDXScholar. Please contact us if we can make this document more accessible: pdxscholar@pdx.edu. 
AN ABSTRACT OF THE THESIS OF James Edem Etim for the Master of Science in Education Presented Apri1 15, 1976.

Title: A Comparison of Eduacation Systems in Nigeria and the United States of America

APPROVED BY MEMBERS OF THE THESIS COMMITTEE:

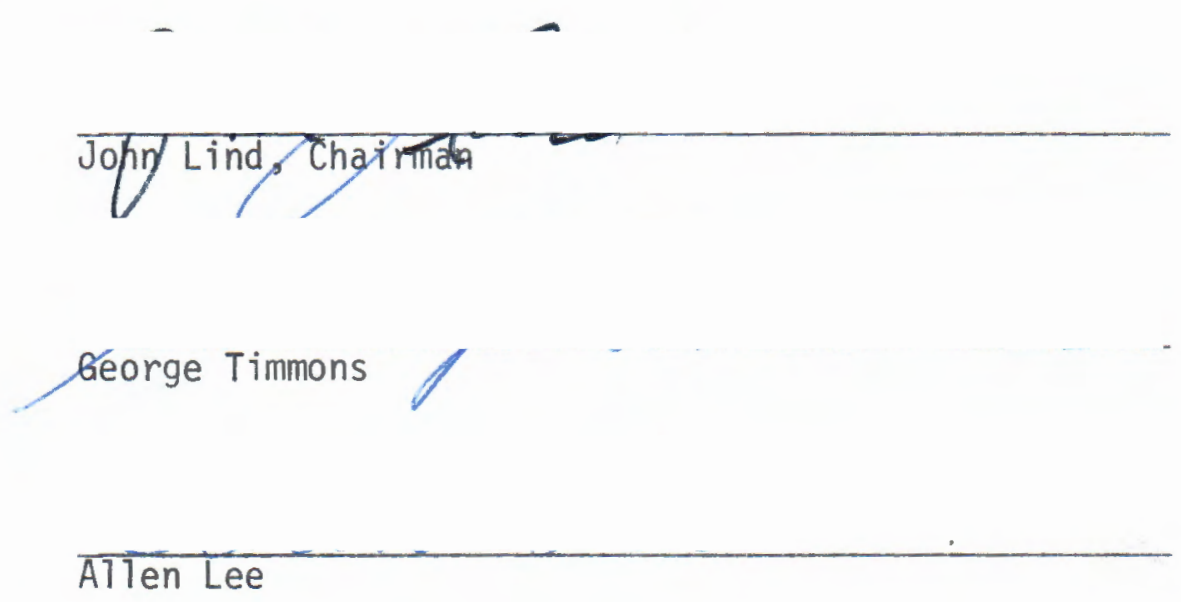

The major purpose of this research study is contrived to determine and evaluate the historical backgrounds of Nigeria and the United States and its implications in the educational policies and systems of the two nations. Both these countries had their humble beginning under the British colonial administration.

The United States is a developed nation while Nigeria is a developing country. The development of the United States schools antedates even the earliest immigrants to the new world in the first quarter of the seventeenth century. The first thirteen states that 
emerged in 1776 were from England and had had the firsthand knowledge of those educational policies and systems. The study has revealed that at least three percent of the male immigrants were university graduates of highly influential calibre. The opposite was the case in Nigeria. The consequence was that the American attitudes toward education follow European concepts. In Nigeria the pattern was to change from Nigerian concepts of education to the European concepts of education.

Furthermore, the period the Americans were under their colonial masters was long enough to give them adequate preparations, financially and otherwise, to cope with any situation. The British rule of Nigeria lasted only sixty years as against one hundred and fifty-six years of British Rule in America with Britian historical background, culture and language.

With Nigerians, the British started a new system whereas in America it was a transplantation of the system. The British colonial masters, perhaps because of what happened to them in America, were not interested in education of Nigerian children. Peter Enahoro recalled once thus; "In the Colonial days, the myth of the Government Scholar was understandable. The British didn't want to rush education. They built schools with reluctance. They didn't build a university until they had to use it as a bribe. And did everything underhanded to discourage the private students."

When they began to help in Education, they introduced British educational policy and system. This was not done until 1925. The philosophy of education, naturally, is typically British. The real 
education began with the missionaries in 1842. As in the United States in the seventeenth century, the kind of education first brought by the missions aimed primarily at religious education, and Nigerian education in the early stages was interwoven with evangelism. The missionaries relentlessly pursued efforts to educate the Nigerian people in spite of the difficulties encountered at the time.

The ultimate aims and evolution of education in colonial Nigeria did not materialize until the Phelps-Stokes mission to Africa (1920-24) was undertaken. The British colonial administration produced a report which states in part, "Memorandum on Education Policy in British Tropical Africa." In that report a comprehensive statement of policy of British education in her African territories was set down for the first time.

The bridging of the hiatus existing between schools and the communities was stressed in another British policy paper; "Education in African Communities, 1935," as well as another report paper, "Mass Education in African Society, 1944."

The Nigerian Ten Year Education Plan also appeared in 1944. On the plan emphasis was placed on these aspects of education:

a. the type of education must be suitable for the needs of the country;

b. better conditions of service for teachers employed by the missions;

c. more financial assistance to missions and other voluntary agencies;

d. financial assistance to native administrations in order to 
assist them to maintain efficient staff of teachers and expand education in their areas;

e. control expansion within financial limits

As Nigeria approached her independence, the American-trained Nigerian nationalists appeared on the scene. In 1954, when Nigeria became a Federation, the policy of education became the regional Governments' affairs. The politicians, particularly in the then Eastern Region where the leader was an American-trained graduate, changed the system to the American way.

The above trend of events has placed more emphasis on the role of education for national reconstruction, economic development and demand for increased educational services and programmes to match the national philosophy, of education and stated objectives of educational outcomes .

There are two implications arising from the financial crisis depicted by the critics both within and without Nigeria. First, ability to cope with the present and future educational needs requires information about, and knowledge of different shifts that have occurred in financing education. Secondly, a recognition of such a crisis provides the need for a more systematic budgeting procedure for education within the total economic and social development of Nigeria. If lasting greatness is to be achieved in education, as in the United States, rigidity and traditionalism will have to be overcome. This demands an open mind regarding the future and a flexible philosophy of life. Greatness in education does not depend upon physical resources, nor upon external structure; rather, it depends upon vision 
and dedication and enthusiasm so that human resources are explored and cherished.

Therefore, to achieve its goals, Nigerian educationists must rely still on cooperations of, and emulation for vision, dedication and enthusiasm of their counterparts in the United States in matters pertaining to education. Like Francois Marie Avouet Voltaire I say, "Nothing enfrancises like education. When once a nation begins to think, it is impossible to stop it." 
A COMPARISON OF EDUCATION SYSTEMS IN NIGERIA AND

THE UNITED STATES OF AMERICA

by

JAMES EDEM ETIM

A thesis submitted in partial fulfillment of the requirements for the degree of

MASTER OF SCIENCE

in

EDUCATION

Portland State University

1976 
TO THE OFFICE OF GRADUATE STUDIES AND RESEARCH

The members of the Committee approve the thesis of James Edem Etim presented April 15, 1976.

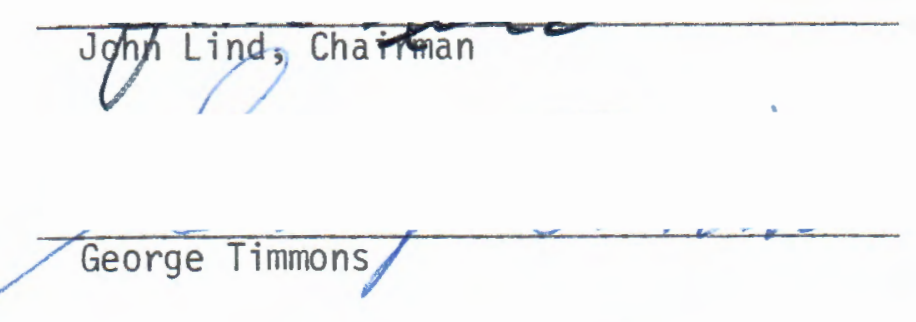

Allen Lee

Approved:

Ronald $G$. Petrie, Dean of the School of Education

Richard B. Halley, Acting Dean, Office ofraduate
Studies and Research 


\section{ACKNOWLEDGEMENTS}

Although it would be impracticable to mention the names of all those who have given me inspirations and encouragements and who have contributed valuable suggestions, I would like to acknowledge my indebtedness, deep gratitude and valued appreciation to Dr. John Lind who has been boudlessly kind enough to sacrifice his leisure hours to study the first drafts of this research and to correct and make valuable suggestions that make it a success in the end; Drs. George Timmons and Allen Lee as well as C. W. Bursch who helped me to get familiar with this course at the initial stages of it.

I wish also to thank the staff of the University Library West of which Mrs. Majel M. Warren and Miss Kathleen Greey were leading figures to help me in my research, and the secretary to Dr. Lind, Mrs. Elaine Hadley who has been kind and approachable to me all through.

These acknowledgements cannot be considered complete without mention of my dear wife, Agnes, who proved so helpful and steadfast under pressure to send me materials and encouragements as well as $\mathrm{Mr}$. and Mrs. James Essien for encouragements and necessary advice on this study. 


\section{PREFACE}

To compare Nigeria educationally with the United States is like comparing an elephant with an opposum in physique. Nigeria, excluding Lagos which became a colony in 1862 , became the Northern and Southern Protectorates of Nigeria in 1900 and amalgamation of the two Protectorates came to existence in 1914. She became independent of Britain forty-six years after the amalgamation.

America was discovered in the 15th Century. Many European nations rushed to explore and colonize the New World instantaneously after the power of the Pope had been weakened by the reformation. England's defeat of the invincible Armada in 1588 weakened Spain's prestige and power throughout the world, but bolstered English pride and encouraged England to reach out for a world empire. In 1607 the first English colony was founded at Jamestown in Virginia. In 1620 the Pilgrim Fathers founded Plymouth (Massachusetts) as the first settlement of a permanent nature in New England. In 1632 Lord Baltimore founded Maryland for the Catholics. Since the Protestants outnumbered the Catholics the Anglican Church became the established church in the colony. Very soon there were thirteen British colonies scattering from Massachusetts to Georgia.

The colonists soon started schools to teach their children to read and write. They taught them their ways of life in Europe, their mother continent. The primary aim of some of the settlers was to achieve religious and political freedom. These could only be achieved 
if each individual could read and write and understand the Bible. The New England colonists felt a distinct obligation to educate the children to save their souls. ${ }^{1}$ Another tremendous motivating force in the development of Education in New England was that approximately three percent of the adult men were highly educated university graduates. For more than 150 years the colonists battled to put the educational system and policy in order. That was why they could produce enough men to work during the battle for independence in 1776 .

The purpose of this study is to present a picture of the interlocking relationships between educational policies in Nigeria and the United States. It is obvious, that some of the states which were led and are still led by the graduates of the State's Universities or Colleges follow the State's policies and systems, while those states led by the British and Commonwealth graduates follow the British policies. When the Federal Government will take over all schools from the States in September 1976, the American policies should be adopted. The reasons are these. The U.S.A. is the oldest outgrowth of the British empire, having been under her for over 150 years while Nigeria had served for only 46 years. She has been a sovereign nation for 200 years compared to Nigeria's 16 years.

Further, the number of Nigerians who have been graduates of American universities and colleges have outnumbered all others together.

Finally, in recent years, American educators have approached the problems of Nigeria education scientifically. The most noteworthy,

1Massachusetts Historical Society for the year 1792 Vol. 1, p 242. 
comprehensive and imaginative study of Nigeria education vis-a-vis the whole complex of African education was undertaken immediately after World War I by the Phelps-Stokes Fund New York, led by Dr. Thomas Jesse Jones.

It is the considered view of the author, therefore, that Nigerian educationists should continue to adopt and adapt United States' policies in education and conduct experiments in the sphere of curriculum to facilitate the formulation of principles which will be good for Nigerian education. 


\section{TABLE OF CONTENTS}

PAGE

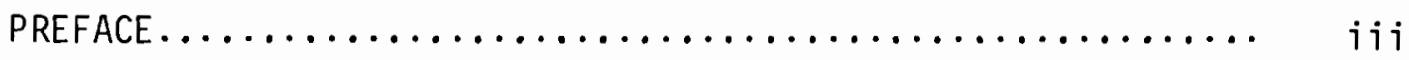

ACKNOWLEDGEMENTS $\ldots \ldots \ldots \ldots \ldots \ldots \ldots \ldots \ldots \ldots \ldots \ldots \ldots \ldots \ldots \ldots \ldots \ldots$

CHAPTER

I PURPOSE OF THE STUDY........................ 1

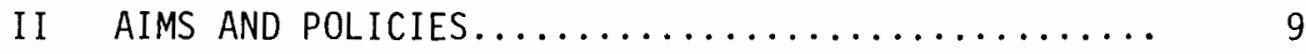

II I THE NATIONAL SYSTEM OF EDUCATION.............. 24

Structure......................... 25

Responsibilities...................... 26

Legal Basis of the Educational System....... 27

IV EDUCATION ADMINISTRATIVE STRUCTURE............ 42

Responsibility of the Federal Government..... 42

Responsibilities of the State Governments.... 44

Finance......................... 48

$\leqslant$ School Buildings...................... 53

Equipment and Supplies................. 55

$\checkmark$ OPERATION OF THE EDUCATIONAL SYSTEM............ $5:$

Inspection....................... 58

Administrative Standards................. 64

Examining Bodies..................... 65

× Teaching Staff...................... 67

Education Planning..................... 81 
viii

$\geq$ Quality of Education................ 85

Curriculum..................... 87

VI CONCLUSIONS, RECOMMENDATIONS AND IMPLICATIONS..... 92

Conclusions....................... 92

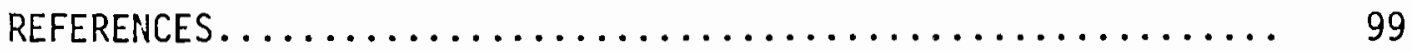




\section{ACKNOWLEDGEMENTS}

Although it would be impracticable to mention the names of all those who have given me inspirations and encouragements and who have contributed valuable suggestions, I would like to acknowledge my indebtedness, deep gratitude and valued appreciation to Dr. John Lind who has been boudlessly kind enough to sacrifice his leisure hours to study the first drafts of this research and to correct and make valliable suggestions that make it a success in the end; Drs. George Timmons and Allen Lee as well as C. W. Bursch who helped me to get familiar with this course at the initial stages of it.

I wish also to thank the staff of the University Library West of which Mrs. Majel M. Warren and Miss Kathleen Greey were leading figures to help me in my research, and the secretary to Dr. Lind, Mrs. Elaine Hadley who has been kind and approachable to me all through.

These acknowledgements cannot be considered complete without mention of my dear wife, Agnes, who proved so helpful and steadfast under pressure to send me materials and encouragements as well as Mr. and Mrs. James Essien for encouragements and necessary advice on this study. 


\section{CHAPTER I}

PURPOSE OF THE STUDY

The purpose of this study is to determine the like and the unlike educational policies of Nigeria, a developing country and the United States of America, a developed country. Basically, the Nigerian and the American school systems are the expression of hopes, desires, ambitions, and values held by those who have made the two nations what they are today.

The period under review begins with the coming of the European Christian missionaries to the Nigerian Coast and the colonization of America by European nations. In this thesis, I shall make an attempt to show the interrelationships between educational policies in the two countries up to the present. I begin first, however, with a succinct historical retrospect.

Prior to the coming of the European nations, first the Portuguese in the 15th century to Benin, and then other nations, Nigerians had their own system of education whereby the young individual was taught to conform to the appropriate social customs and tradition of his tribe or clan. He was also to learn a trade of one type or another, in order to be a good citizen. The Portuguese missionaries arrived in Benin in the early part of the 16th century and began to teach the Benis brass work and to read and write the Portuguese 1anguage. By 1520, the fetish priests in Benin revolted against the missionaries and forced 
the Oba (king) to drive them away from the city. They then established the Soa Thamae Island. From that time, the people returned to the Nigerian systems of education but maintained the brass work taught by the Portuguese until formal education started in Southern Nigeria in the early 1840's by the European Christian Missionaries.

The first education ordinance for Lagos was enacted in 1882 when Lagos united with the Gold Coast Colony (now Ghana). The first inspector of schools was appointed in 1892 in the person of Mr. Car. The promulgation of an education code in 1903 heralded the establishment of an education department for the protectorate of Southern Nigeria. The rapidly changing conditions in the early twentieth century, the development of the school system on the basis of cooperation between government and mission, the need for increased educational expenditure by the government, and effective control of all types of schools led to passing of a code in 1926 (Ordinance No. 14 of 1926 for the Northern Provinces and No. 15 for the Southern Provinces) which remained untouched until after World War II.

The most populous Moslem Northern Provinces had traditional Koranic schools long before the Protectorate came into existence in 1900. The western type of schools were begun by the government in collaboration with the native authorities and, in pagan communities, schools were developed by the missions under similar conditions to those in the south.

After a period of steady but quiet growth during the 1930 's the Nigeria school system expanded rapidly during the next decade. In 1945, a ten-year plan was formulated and funds for capital works became 
available under the Colonial Development and Welfare scheme. In 1947, an education development was put into effect, and in 1948, after an investigation of grant-in-aid had been made, a new ordinance was enacted to revise the administration of the school system throughout the length and breadth of the country. Basically, the present system of education in Nigeria stems from this.

Constitutional changes made it necessary to re-enact the 1948 Ordinance in 1952 to make it applicable to the newly established regions. The Adaptation of Laws (Ordinances) on October 1, 1954 when Nigeria became a Federation, provided for the devaluation of the functions of the Central Authority on Regional Directors and Regional Boards.

Legislation thereafter developed regionally. Although at first the 1948 Ordinance retained main provisions, ordinances introduced later changed significantly. At any rate, in spite of all the changes, the essential framework remains the same.

In comparison to the history of American education policy the humble beginning was the same but the approach was different, for the American colonists came from highly educated nations of Europe.

The early settlers in the New World brought with them their respective political traditions, religions, styles of architecture, and social customs. When they were faced with problems, it was natural for them to do the same thing that men have done throughout the ages - they drew upon the experiences with which they were familiar. As a consequence, the first institutions in the New World were built on the foundation of the life and customs of the 01d World. 
Essentially, it was a process of transplantation. Early schools, therefore, were patterned in the European tradition and the attitudes toward education followed European beliefs. 1

As in Nigeria, the Puritans of New England, the Dutch Protestants of New York, the Quakers of Pennsylvania, Presbyterians, Mennonites, Lutherans, Anglicans, and last of all Catholic churches established schools to train the children of their followers from about 1630. The schools differed from one another because each reflected a concept of school that they left behind in Europe. Most poor children had no formal schooling at all. They only learned through apprenticeship. Those who attended elementary schools were taught the three R's and religion. The missionaries opened secondary schools for the children of the wealthier parents. They depicted most of the European schools. The teachers were not better prepared. In 1636, Harvard College was opened to train teachers to teach Latin for the ministry.

In 1642, Puritan Massachusetts passed a law requiring that every child be taught to read, for it had become evident that the dame schools and the private tutors did not guarantee that all children would attain the basic requirements of literacy which the Puritan societies required. The law charged the local magistrates in each town with "the care and redress of this evil".2 As Marshall pointed

lRichey, Robert W., Planning for Teaching: An Introduction to Education, McGraw-Hill Book Company, New York, 1968.

2Massachusetts Bay Colony, School Law enacted 1642. 
out, "Here was the first modest step toward two characteristics of our modern educational system - universal education and compulsory education. For the first time, a government had declared that all children should be taught to read and made its purpose enforceable under 1aw." 3 When it became evident that the law was not strictly enforced, the Massachusetts Public School Law was enacted in 1647. The law required each town of fifty or more families to establish an elementary school and every town of one hundred or more families to maintain a grammar school as well. This law was known as the "01d Deluder Satan Law".4 The system was difficult to create in the Middle Colonies because of the variety of religious sects.

In the South, the planter's children were taught by private tutors or sent to private boarding schools in the colonies or in England. All told, the aim of colonial education, as well as in Europe at that time, was to inculcate Biblical religion but in the South, the curriculum and organization were more secular than in the Puritan New England. They vigorously supported the classical languages and literature. They maintained public elementary schools, but secondary and higher learning was exclusively in the hands of weal thy landowners.

3 Ibid. p. 49 .

4United States History for High Schools, Section 2, "Education", 
In the Southern Colonies, several free schools were established with the private contributions of public-spirited citizens. These schools were known as paupers because families had to declare themselves openly to be paupers in order to send their children there. Many parents who could not afford to pay the rates charged and who refused to be advertised as paupers had to keep their children out of school. Consequently, a large proportion of young people grew up illiterate. The law to constitute a form of compulsory education was passed. In it, the colonists followed the European custom of apprenticing the orphans and the sons and daughters of very poor families. The local magistrate could apprentice such a child to a master craftman, who would teach the child his trade, give him board and lodging, and provide instruction in reading, writing, and religion. The child, in turn, agreed to help his master unquestionably in his work. Far too often, it was found that the masters were more interested in the apprentices' services than in providing good basic learnings for the children.

In 1635, the first college preparatory school was founded at Boston, called Boston Latin School. In 1636, Harvard University was founded as the first permanent college in English North America. These were followed later (1693) by College of William and Mary founded by the Episcopal Church. In 1701, the Congregational Church added Vale University and in 1746, the Presbyterian Church founded Princeton University. As the colonists were mostly from England, the religious influences and English collegiate tradition were dominant factors in the establishment of the first American colleges. 
As time went on, the businessmen (farmers, soldiers, sailors, merchants, industrialists) began to question the appropriateness of the narrow and rigid college preparatory curriculum of the grammar school to train youngsters for a practical world. The men were led by Benjamin Franklin, who established the first public academy in Philadelphia. This brought education closer to the people's needs of everyday 1 ife by teaching such subjects as history, geography, accounts, geometry, algebra, surveying, modern language, navigation and astronomy.

After the Revolutionary War, the states began seriously to support free schools for the children. A number of noteworthy leaders emerged to help in the fight. Particularly noted were Horace Mann of Massachusetts, who became known as "the father of the American free public school," Thaddeus Stevens of Pennsylvania, John J. Pierce of Michigan, Caleb Mills of Indiana, Robert J. Breckinridge of Kentucky, Ninian Edwards of Illinois, and Lyman Rucker and Calvin Stowe of Ohio. This began in 1820 with the elementary schools. In 1837, Massachusetts established the first state board of education. The secretary was the lawyer and politician, Horace Mann. One of Mann's many reforms was the establishment of the first public normal (teacher training) school in the United States. State after state imitated Massachusetts' example. The attendance was still poor because most people did not send their children to schools.

In 1852, Massachusetts passed the first part-time compulsory school attendance law. New York State enacted a similar law in 1853, but the question of the right of a state to compel school attendance 
was debated for half a century thereafter.

In 1857, the United States Department of Education was established with Henry Bernard as its first Commissioner. The state and local governments were vested with the responsibility for and control of education, while the federal government acted as the GodFather.

In 1890, Connecticut enacted the first compulsory full-time attendance law which was adopted by 32 states by 1900 . In 1895, a committee of fifteen was set up by the National Education Association of Elementary Education. The report outlined an eight-year educational scheme/programme stressing matter deemed suitable for every child to master.

By 1918, the legislation for compulsory school attendance was in force in the then forty-eight states. Like Nigeria, provisions of the 1 aw varied from state to state and region to region with respect to the required number of days of attendance, the compulsory age period and the measure to enforce compliance.

This was also the period of reorganization of secondary education. A commission on the Reorganization of Secondary Education was set up which issued its momentous report shortly after. The Cardinal Principles of Secondary Education was reorienting people to the central purpose of education, a free society. By 1928, the junior high school was established at Columbus, Ohio and Berkeley, California. 


\section{CHAPTER I I}

\section{AIMS AND POLICIES}

As Nigeria and the United States started educational activities under the same Colonial masters, although in different categories, their national aims and philosophies of education seem to be alike. Factually speaking, the first group of politicians who took over the governments of Nigeria from the British Colonialists were mostly those who were educated in American colleges and universities. The Americans of the original thirteen states initially had the philosophy of determining for themselves how their children should be instructed as part and parcel of their democratic way of life more than a century and a half before the United States emerged as a sovereign nation in 1776. Nigerians could not do this because they did not have the same background as the American Colonists who came from England and other civilized countries of Europe. The policies of education in Nigeria were based on the English policies and directed by the Christian Missions.

The first ordinance enacted in May 1785 was a provision to reserve lot \#16 of each township for the maintenance of public schools. Another education ordinance enacted in 1787 specified that, religion, morality and knowledge being necessary for good government and the happiness of mankind, schools and the means of education should be encouraged. In 1788, the Constitution of the United States was framed by Jefferson and company, and the Federal Government came into 
existence. Each state remained sovereign for most internal purposes, including education.

The democratic way of life, the needs of the people, their philosophy, their control and regulation of education and federal interest combined to produce a continuing impact on education in the nation. They underlie and help to shape local, state, and federal policies in education and to influence the scope for such policies.

The above shows that the broad national aims of the state's education are the same as the political, social and economical goals embodied in the Constitution, "to form a more perfect Union, establish Justice, ensure domestic Tranquility, provide for the common Defense, promote the general Welfare, and to secure the Blessings of Liberty to ourselves and our posterity."

During the nineteen-fifties, when the Governments of the regions of Nigeria attained self-governing status, the idea of the American concept (which was then nearly two hundred years old) of using education as an instrument of economic, political, and social policy became an established principle of ideology of a responsible Government, freed for the first time from Colonial control. Since then, the Government has recognized the role of education in promoting national development and has since provided the conceptual framework and practical dimensions within which subsequent education policies have been defined and elaborated.

Basically speaking, America is a developed nation while Nigeria is a developing nation. Nigeria has to start now what America started two hundred years ago. The first six-year-development plan of the 
Federation of Nigeria defined the main aim of education as providing an informed electorate without which a democratic state cannot survive. This led to the adoption of educational policies with positive practical purposes. These were: a) achieving concrete results in terms of economic and social progress, b) acceptance of educational expenditures on an unprecedented scale as a public responsibility, and c) a strategic item of development investment.

While the United States as an established nation is endeavoring to recapitulate its broad aims of education by preservation, further expansion and transmission of knowledge and development of attitudes, skills, and techniques which will serve to promote and improve the welfare of all (while recognizing and protecting the integrity of each individual). Nigeria is endeavoring to ensure that education effectively fulfills its economic role of producing competent citizens and manpower for manifold needs of a developing society. It is necessary, therefore, to carry out surveys of the existing manpower situation and to work out projections of future manpower requirements.

At present, the Governments of the Federation of Nigeria are in the process -- through reformation of curriculum and regulation of faculty programs -- involving a selective approach to the programming of manpower training so as to ensure that the product of the school system corresponds in more balanced numerical proportions to the needs of the country in respect to every profession, trade or occupation, and at every level. The highest priority at the present time is the training of scientific, technical, and technological manpower in the whole range of relevant disciplines at the tertiary level, and 
technical vocational agricultural training at the secondary level. Of critical importance is the training in sufficient numbers of technicians and skilled tradesmen in the middle to provide the essential services needed in every field of technology. Elementary crafts are being produced in the science classes of the primary schools in some areas, while a start has been made in introducing science teaching and agricultural education in others.

A major area of public concern and one which influences policy is the prospect of jobs for the primary and secondary school levels and university graduates. The grammar school or academic tradition has for years dominated the school system and, to a very large extent, still does. Nowadays, several thousands are leaving the schools and colleges with literary types of education and with no training in practical skills. Suitable employment opportunities, clerical, commercial, and administrative occupations are becoming scarce. In consequence, the Governments of the Federation are all committed to the policy of diversifying context of the school curriculum to prepare the pupils for a much wider range of occupations than before.

To round it all, obligatory manual subjects are to be introduced, vocational training to be increased, and agricultural education expanded. More science laboratories are to be built and equipped. Commercial education is to be made available to an increasing number of girls. By providing funds for such purposes, the Federal Government intends to promote the diversification and expansion of secondary education. 
These general practical aims of education are being pursued with a deep concern for the quality and ethnical content of education. The important role assigned to the churches in the provision of public education at the primary and the secondary levels is attributable to this fact. While writing this, the Governments of Lagos, Mid-Western, East Central, Rivers, and South-Eastern States have taken over schools from the churches. The Federal Government is anxious that the young are taught to live as good, useful, public-spirited citizens with decent moral values and to provide them with training for employment. The recent news is that the Federal Government is going to make education once again the Federal Government's concern and enact compulsory free primary educations.

The governments of the Nigerian States, like the United States of American, have autonomous responsibility for education at all levels within their respective regions from 1954 with three regions of East, West and North and Mid-West in 1963 until twelve states were created in 1967 by the Supreme Military Council. The Federal Government had a Ministry of Education which was responsible for the education within the former Federal Territory of Lagos until 1968 when the Lagos State took over. The Ministries of Education are responsible for formulating general policy which may be applied at the direction of Parliament (1954 to 1968 in the Federal Territory) or the Cabinet or by the order of the Commissioner of Education as appropriate. The Governments have the policy or machinery for consultation in the form of statutory boards of education or education committees to which the leading citizens, representative of teachers' organizations, voluntary agencies 
(now Local School Board) in some states, the heads of educational institutions, trade unions and employers' organizations are appointed by the Minister of Education.

At the official capacity, there exists the Joint Consultative Committee composed of top professional and administrative staff of the Ministries of Education. It has no statutory status. It was established administratively by the agreement of the Ministries of Education for coordination of policy regarding matters of common interest.

University education and other types of tertiary education also came within concurrent authority of the regions and the Federal Government and (since 1968) the states. Basically, the universities were autonomous until 1975 when the Federal Military Government took over all universities with complete freedom to decide on and follow their policies in academic matters, as well as in their internal government and administration. They derive their funds, however, from the Governments of their respective regions (now states) and receive substantial subsidies from the Federal Government.

Factually speaking, there is understanding and tacit acceptance in responsible university and government circles of the fact that the universities should serve the needs of Nigeria for high-level manpower in all fields. In spite of the fact that the universities jealously maintain the independence in academic matters, they are fully responsible to these demands. They received guidance from the National Universities Commission, which is responsible for administering the federal grants on the priorities which they should observe in planning 
their development so as to take account of trends in the country's manpower supply. The National Manpower Board plays the strategic role in carrying out the studies and surveys and providing the statistical and other data on which the priorities for manpower training are based. One of its own sources of information is the National Register of Students which is maintained in a section of the Federal Ministry of Education and which provides comprehensive and up-to-date information about students who are undergoing courses of training in institutions of higher learning in Nigeria and abroad.

As a matter of fact, all the governments of the Federation regard public education as the responsibility of the state, and, throughout the country, the system of public education operates within the framework of laws and regulations enacted by the Government and administered by the Ministries of Education. Up to 1970, however, over ninety percent of primary and secondary schools as well as Teachers' Training Colleges in all states, except in the Northern States, were under the management of voluntary agencies. These agencies are mostly the Christian and other missionary societies. Proprietors own and run the schools with the aid of Government grants. Government policy on this issue has always been in favor of partnership between the Government, the voluntary agencies and other approved proprietors. Leonard $\mathrm{J}$. Lewis, in his article titled "Prospects of Educational Policy in Nigeria" has this to say.

The educational system that Nigeria inherited when it became independent was the joint product of the Christian Missions, the Colonial Government, and the efforts of the indigenous people. The indigenous people contributed voluntary aid, and in Northern Nigeria provided the Koranic 
schools. The Government contribution consists of an increasing element of financial aid to the mission schools and colleges, the direct provision of schools and colleges for advanced education, and in some instances, elementary schools for minority groups to whom mission education was not available or not compatible with religious or other scruples. ${ }^{5}$

But in 1955, the wholly and entirely Nigerian Governments one after another acknowledged and accepted the principles of full state responsibility for developing and financing public education on a massive scale so as to promote the social and economic development of the community as a whole. The then Governments of Eastern and Western Nigeria introduced Universal Free Primary Education in their respective regions and the Federal Government did this in the Federal Territory of Lagos. This was followed by a rapid expansion of education at the secondary level, attention being devoted to the development of Sixth forms, and the establishment of a new university in each of the then existing regions within the next few years. All this has resulted in a vastly increased and growing rate of expenditure on education at all levels.

Yet the voluntary agencies retained their quasi proprietary status, their independent initiative, their denominational institutions, their control of over ninety percent of the primary and secondary schools as well as the teachers' training colleges. In fact, the management of the new free primary schools was largely attributed to them, with Government funds to cover the initial capital and virtually

5Lewis, L. J., "Prospects of Educational Policy in Nigeria", Education and Policies in Nigeria, by Hans N. Weiler, p. 240. 
one hundred percent of the recurrent costs until early 1970 when some states (example: East-Central, Rivers, Mid-Western and South-Eastern States) took over schools.

There is thus a policy of partnership between the Government and the voluntary agencies in education at the primary and secondary levels, in which the government lays down the policies, enacts laws and regulations, provides the inspectorates, carries out the over-all planning and administration, pays the teachers' salaries, and bears the major (sometimes one hundred percent) part of the capital and recurrent costs, while the voluntary agencies take charge of the management of their groups of schools in the public system.

In 1965, the National Joint Negotiating Council, made up of representatives from all Governments of the Federation, local authorities, teachers' unions, and voluntary agencies, and established by the joint action of the governments of the Federation to examine the conditions of service of the teachers, recommended that the regional and/or local school boards should be established to deal with appointments and promotions within the teaching service, discipline, collection and disbursement of funds and such other duties as the Minister of Education may from time to time direct.

Although uniform scales of salaries, conditions of service anc other laws and regulations are nationally enforced, each proprietor or voluntary agency has a wide margin of freedom in regard to such matters as the recruitment, training, tenure of appointment and promotion of staff. The regional or local school boards, if created, will take over 
the relevant powers and functions of the separate denominational education secretariats and thus establish a unified system of education for all schools at the primary and secondary schools as well as teachers' training colleges and other institutions of higher learning within their respective areas of authority. The South-Eastern, EastCentral, Rivers, and Mid-Western States have already created the local board system. It is hoped that other states will follow their example in no long distant date. In this way, the teaching service, which is divided now between the controlling voluntary agencies and proprietors, would become integrated for administrative purposes under the authority of the local boards. This arrangement, when fully done, would free teachers from denominational isolation and open the way to competition for promotion on a broader territory and on the basis of merit.

Local Government bodies have the power to establish, and have in fact established, primary and secondary schools in their provinces, districts and towns. The number of such schools is relatively small. They are staffed and financed by the local authorities themselves who are responsible for all primary schools in their areas including schools managed by the voluntary agencies which do not receive direct grants from the regional Government, but are financed by local taxes. In Northern Nigeria, education at the secondary level is provided by the State Governments and the voluntary agencies.

The role of the community in education in Nigeria takes a number of characteristic forms in various parts of the country. Very few parent-teacher associations exist and their activity is hardly noticeable, but a great deal of community interest in education is 
evidenced by the amount of public discussions of the subject. The community participates in education by voluntary effort and payment of special levies. (In the voluntary agency system, the community built and equipped schools and paid the assumed local contribution. They elect members to form school comittees to care for the schools.) In many parts of the country, noticeably the former Eastern Region (now South-Eastern, East-Central and Rivers States), societies and unions organized for self-help by particular ethnic groups, villages or districts, have built and equipped primary and secondary schools in their villages or districts and invited any agency of their choice to run them on their behalf. This voluntary effort in collaboration with the churches has made a significant contribution to the provision of basic educational facilities in various parts of the country. Apart from building and running their schools, some of these community organizations have awarded scholarships for higher education to their own students on the condition that the latter undertake to finance the training of other qualified students on the completion of their courses. Similar voluntary efforts have been made by other tribal unions as well as other smaller family groups.

It is the policy in some places that local government bodies have to impose special levies to raise funds for primary education in their areas.

A number of private schools exists, mainly at a secondary school level. They mostly offer technical and commercial courses although some offer grammar-school courses. Normally, these are called private schools in the sense that they do not receive Government grants because 
they have not attained the required standards for approval by the Government even though they have official permission to function. At the primary level, mostly in the larger towns and cities, there are private fee-paying preparatory schools which claim to have higher standards than those of the free primary schools in the public school system. There is also a great deal of activity in the pre-school sector by private nursery school proprietors, operating in the larger towns and cities where there is a growing demand from working mothers for day nursery.

Because there are fewer facilities for primary and secondary education in the Northern Region (States) than in the other regions, the Federal Government has decided to do everything possible to intensify the rate of educational development there. The Federal Government Sessional Paper No. 3 of 1961 has this to say.

The objective in the North should be to approach parity with other regions in the Federation, and in any event, development must be so planned as to give, by 1970, a total enrollment in the Northern Region of not less than fifty percent of the children of the primary school age. Federal Government is resolved to assist the Northern Regional Government financially to achieve this result. 6

It is the duty of the Governments of the Federation of Nigeria to provide free education at the primary level to all pupils of primary age. Fees are charged to secondary schooling level and upwards, but Government scholarships are available for secondary education, particularly for pupils who come from areas where general development

6The Federal Government Sessional Paper No. 3 of 1961. 
has been slow. Government scholarships are available also for undergraduate and post-graduate studies at universities and other institutions of higher learning in Nigeria and abroad. With the number of universities being increased in the country, the policy of giving scholarships abroad is minimized except on special courses.

Girls have the same facilities for education as boys, though the percentage of girl pupils is smaller. A number of special schools for handicapped children exist.

The Federal Government White Paper on educational development for the period of 1961 to 1970 was largely based on the concept of education as a means of producing trained manpower in sufficient numbers in the various disciplines to enable the Nigerian economy to dispense with the assistance from outside.

It is now known that while there are critical shortages of manpower in some fields, particularly in the scientific, technological, medical, agricultural and some other teaching fields, there is overproduction of high-level manpower in other fields. It is the policy of the Governments of the Federation to correct the imbalance by using the machinery of the National Universities Commission, which administers Federal grants to the universities. The aim is to increase the supply of the qualified candidates for scientific, technologicai, medical, and veterinary studies at the post-secondary level, and to increase the potential supply of science and mathematic graduates to fill the numerous vacancies now existing in the secondary schools. Prior to 1975, education in the independent Nigeria was under jurisdiction of the regional (state) Governments. There was no national 
system of education as such, but the system of education in all the regions (now states) was basically the same. The scope of education included literary, scientific, technical, commercial, agricultural, and social studies at all levels, and the higher level embraces professional courses such as medicine, law, engineering, economics, accountancy, dentistry, pharmacy, veterinary science, librarianship, and management studies at the post-secondary level. The entire complex of institutions and other training establishments organized and financed directly or indirectly under the aegis of the Governments of the Federation or the statutory corporations and functioning either under the control and supervision of the Ministries of Education or under independent management. This consists of pre-primary (Preparatory and Infants classes), primary, secondary, youth education (vocational and technical), higher education including teacher's training and adult education. In some regions, literacy was and still is treated as an aspect of community development. and in some the programs are dealt with by the Ministry of Education. Whatever it is, the concept of such programs as an integral part of the education system has not yet been generally adopted for the purposes of planning, finance, and administration.

The United States, having been a past-master and long experienced nation in matters pertaining to education, has concisely expressed. Government policies in education. Three principles constitute the framework of reference for the policy-making and approval at all Tevels in respect to education, namely: 1) The control and regulation of education in general throughout the nation decentralized. 
2) Education is basic to freedom and progress in the nation's republican democracy. 3) Everyone is entitled to equal opportunity for high-quality education. Within this framework, policy-making and approval relating to the control and regulation of education takes place at the levels immediately below federal level, or, on their delegation, at the local level. At the federal level, the President proposes and the Congress passes legislation setting forth the nation's policy for promoting education through financial and other assistance. In total, federal policy aims at assistance to education for the benefit of all those who can profit from the opportunity, irrespective of sex, age, race, color, creed, or national origin. It further aims to help in discovering and encouraging the talented and the economically, mentally, or physically disadvantaged, while also helping those with more nearly average endowments. At this juncture, Nigeria is on the path to following the States' example. This policy also encompasses help for the construction of adequate new facilities or the modernization of existing facilities, both public and private, through grants or low-interest loans.

There is no single set of accepted priorities for federal assistance. Within the framework of federal legislative provisions for allocation of funds on the basis of population to be educated, concentrations of children from low-income families, and the like, country-wide advisory groups are called upon to assist the Government in establishing criteria for determining priorities. These priorities are then established below federal level and territories and within an individual state or territory. 


\section{CHAPTER III}

\section{THE NATIONAL SYSTEM OF EDUCATION}

There is no centralized or nationally directed system of education for the United States as a whole. Instead, there are thousands of different systems, some public and some private. Each one operates under such policies and regulations for public education or such licensing requirements for private educations as are operative in the particular state where it is located. Characteristic of these policies, regulations, and licensing requirements is the recognition that education should be responsive to the needs of the people and the provision for delegation to the local public level or to the private sponsoring agency of a marked degree of authority and responsibility. One result is enormous diversity among the systems of education throughout the country. At the same time, the freedom of the system to experiment and the procedures for sharing information on the results of the experiments have made for a unity among the systems and a general similarity in their programs.

Any school or higher-education institution established by public authority, controlled and operated by publicly elected or appointed officials and supported by public funds is called a public school in the United States. Other schools, and higher-institutions of learning, privately, denominationally or commercially established, operated and financed are known as private or non-public schools. These systems 
compare squarely and factually with those adopted by Nigeria. Indeed, some states have begun already to change the name to Public School noticeably, the South-Eastern State. This may be changed as the Federal Government has decided to take over all schools and centralize or nationalize them. She has aiready taken over all universities.

\section{Structure}

Basically, this varies tremendously because not all the rungs of the educational ladder are available in each system since some systems are small or are located in sparsely populated areas, and since there usually are separate systems for higher education, at least above the community or junior college or the technical institute level.

Some of the "head start" programs are organized in classrooms and some are health or recreational programs outside the classroom setting. Paralleling the regular programs for the first to the sixth grades of elementary schooling are the varied day and evening classes to accommodate adults who wish to enroll at the different stages of basic education to overcome English-language deficiencies or fundamental needs in other parts of their general preparation for gainful employment.

Beginning at junior high school and extending to the postdoctoral levels, the structure may parallel or be the same as for the regular programs to accommodate adults interested in informal or formal extension or continuing education. Among the deciding factors are whether or not a particular system is large enough for establish- 
ment of a separate school, department or college of continuing education.

Since the scope of education is very broad within the nation, the programs operating under the structural patterns vary widely. Some are broadly conceived and some are highly specialized for help to meet the varied needs and abilities within the population. Also taken into account are such factors as climate, location in a rural or urban area, and proximity or distance from special facilities or unusual resources. Gordon $C$. Lee has this to say.

This also constitutes a serious and paramount charge upon the schools of America, requiring that they deal in broader perspectives than ever before. We cannot be content with a curriculum which is simply 'Western' or 'Christian' or 'American'. A narrow educational program will not suffice to serve our new international citizenship. 7

\section{Responsibilities}

As stated earlier, the conduct of public education is the responsibility of the states and the localities. Like in Nigeria, the U. S. Federal Government, however, does exercise responsibility for the actual provision of it in respect of the Territory of the Pacific Islands (through the Department of the Interior). In addition to that, the Department of Agriculture operates a graduate school, the Department of Defense operates military-service schools and school programs for children of military and civilian personnel stationed

7Lee, Gordon C., Education in Modern America, p. 16. 
abroad and the Department of Justice has a program of citizenship education for those being naturalized.

Although federal assistance has been provided since $1917^{8}$, the responsibility for financing vocational and technical education is at the state level. A basically comprehensive revision of the approach of such assistance came with the Vocational Education Act of 1963 which is aimed at making vocational and technical education in any occupation not generally requiring a baccalaureate degree available to all who wish it or need it. Factually speaking, it established closer communication and cooperation with the market-place and Federal Employment Service.

Federal funds are available for secondary vocational education, post-secondary vocational education, adult vocational training and retraining, vocational education for persons having academic, socioeconomic or other handicaps, construction of area vocational schools, and ancillary services and activities. ${ }^{9}$

\section{Legal Basis of the Educational System}

The legal basis of the education system is as old as the European Scramble for Africa toward the end of the last century, for it was in 1882 that the first education ordinance for Lagos was enacted. The legal promulgation of an education code in 1903 heralded the

\footnotetext{
8smith-Hughes Act of 1917 (Including George-Reed Act of 1929,
} George-Dean Act of 1936 and George-Barden Act of 1946).

${ }^{9}$ Lee, op. cit., p. 274. 
establishment of an education department for then Protectorate of Southern Nigeria. But before the regional Governments were established, the law under which education was administered throughout the country was the Education Ordinance of 1948 , to which were added the Education Regulations of 1949. The 1948 Education Ordinance authentically provided for the establishment of advisory boards of education for the centre and the regions and the setting-up of localeducation authorities and committees, and laid down regulations for the administration of Government grants to the voluntary agency schools. These regulations also introduced a new system of grant-inaid and set out more detailed regulations for their administration. In 1952 another Education Ordinance was promulgated. By and large, this Ordinance remained in force to become the common source from which all subsequent regional legislation on education has been developed, namely:

Northern Region (now Northern States). The Education Law of 1962; The Education Law of Northern Nigeria 1964; The Education (Genera1) Regulations 1964; The Education Authorities Regulations 1964 and the Grants-in-Aid Regulations 1964.

Western and Mid-Western Regions. The Western Education Law 1954, and subsequent amendments and alternatives. 10

Eastern Region. The Eastern Region Education Law 1956; the Grants-in-Aid Regulations 1957; The Teachers (Disciplinary Provisions) Regulations 1967 .

10This is embodied in the omnibus publication entitied "Education Laws" (Cap 34) 
The Nigerian education laws in general provide a pattern for the administration of education in the respective regions. Indeed, they define the powers of the Minister of Education and designate the public officers responsible, under the Minister, for the provision, control and administration of public education; provide for the establishment, constitution, functions and membership of regional education boards, local education authorities and education committees; provide for the establishment and closure of schools, registration of teachers and school inspections; prescribe curricula for primary, secondary and modern schools and deal with the rights of access to schools without discrimination of grounds of race or religion or language; deal with secular instruction in public institutions and with religious instruction in voluntary agency and community schools.

Rightly, the regulations deal with the administration of grantsin-aid and lay down rules relating to such matters as school accommodation, equipment, enrollment, staffing, the duration of school sessions, and class periods, school records of teachers' records, control of school expenditure and accounts, and the assessment of grants. They lay down other conditions which must be complied with before schools can be approved for grants.

Education laws are prepared by the Ministries of Education which will normally take into account the advisory opinions or recommendations of the boards of education. When all these are done, the draft legislation is then presented by the Minister of Education to Parliament for debate and approval. 
In the United States, the legal basis of education system is more advanced than that of Nigeria, a] though in parts, it is comparatively the same. The democratically liberal system of education is the same in both countries, Nigeria, a young and developing nation, copies most of her education policies from the United States, through the pre-independence leaders who were trained in American colleges and universities, noticeably Professor Eyo I tawho who returned to Nigeria in 1934 with a list of academic degrees and a burning passion to organize national schools as instruments in the war of liberation. He founded the National Education Movement. 11

To begin with, "The Powers not delegated to the United States by Constitution, nor prohibited by it to the States, are reserved to the States respectively, or to the people."12 This, in effect, affirms the philosophy of decentralized control and regulation of education, and undoubtedly and specifically, the power to control education is among those powers neither enumerated by the Constitution for exercise at the national level nor prohibited by it for the exercise in the states.

In reality, legislation authorizing the establishment, $1128-31$.

1iColeman, James S., Nigeria-Background to Nationalism, pp. 218, 12 Article $X$ in the Bill of Rights. 
maintenance and support of public education and regulating the licensing of private education is different for each of the fifty states and five other jurisdictions in the nation. Some of the legislation is found in fundamental state laws. Within the framework of any such constitutional provisions, the state legislature has power to pass bills and the governor to sign them into law for education within the state.

Evidently, the power to control education is not inherent in local self-government. Rather, the states have provided for the establishment of local administrative districts and vested them with extensive authority and responsibility for the establishment, control, and regulation of the schools in their districts.

It would be interesting to note that for nearly three quarters of a century Article $X$ in the amendments to the nation's Constitution served to nullify national legislative efforts to provide for any sort of federal aid specifically for education in that part of the nation already organized into states. The reappraisal of the needs of the people in relation to states' rights and federal powers led to a focusing of attention on the common defense and general welfare clause of the Constitution. One of the consequences, as a matter of fact was a new epoch for education in the United States. Legislative action taken within the framework of a really broad interpretation of this welfare clause ${ }^{13}$ made for the development of the federal-state-

13Article $x$ in the Bill of Rights. 
local partnerships which not only became traditional, but contributed tremendously to the general raising of the capacity, the availability, and the quality of education in the great nation. By and large, in the process, the partnerships contributed to the gradual development of unity among the systems. Although the Constitution did not specifically mention Article 1, Section 8 specified that Congress was to have power for the general welfare of the people. 14 This expression formed the basis for federal support of education. The Bill of Rights 15 defined the role of education more clearly than did the Constitution.

Basically, most of the United States federal laws in the field of education respond to needs common to the country as a whole; some respond to special or unusual needs in a particular geographic area. Evidently, federal programs have been giving more and more comprehensive assistance for education, beginning in the early 1950's and clearly evident by the 1960's. While the trend developed, the type and scope of federal assistance and the way the funds were to be apportioned began to offer a general perspective on national education. Congress, as in the earlier periods, continued to be vigilant in avoiding any legislative provision which might be construed as to permit federal control or regulation of education in the states and included any section in each major law specifying

14Richey, op. cit., p. 437.

15 The Bill of Rights ratified in 1791 . 
in detail that such federal control is prohibited.

Pertaining to public higher education, the tradition of partnership began a federal-state basis. As far back as 1862, 2nd July, Abraham Lincoln signed into law, a bill calling for "Donating of public lands to the several States and Territories to provide colleges for the benefit of agriculture and mechanic arts." This, in the main, established the principle of federal aid to public education without prejudicing the traditional rights of the states and their peoples to control and regulate that education and included an equalization formula for distribution of federal support for education throughout the country.

The law of March 2, 1867 provided for the establishment of a federal entity soon to be known as the Office of Education, wholly and entirely concerned with administration of federal financial assistance for education, the rendering of advisory services, and the conduct of those statistical and other types of research which cannot be undertaken as economically or as effectively by other than a federal agency.

Under the law of 23 February 1917, federal support was authorized for vocational education programs in the fields of agriculture, trade and industry, and home economics, and in the training of teachers, supervisors and directors of these subjects. An amendment 1 aw in 1956 authorized federal support for vocational education in practical nursing. Another amendment authorized funds to help provide vocational education for residents of areas inadequately served and meet requirements for personnel equipped to render skilled 
assistance in fields particularly affected by scientific and technological developments.

The Manpower Development and Training Act of 1962 included authorization of federal funds for training designed to bring the country closer to the goal of full employment and meet the demands of business and industry for higher levels of skill. Federal responsiveness to changing needs underlies the Vocational Education Act of 1963 which authorizes federal grants to help states and the other five jurisdictions develop new programs and maintain, extend and improve the existing programs. The National Vocational Student Loan Insurance of 1965 authorized funds to encourage establishment of adequate loan insurance programs for vocational education students.

A law of 10 May 1950 provided for the establishment of the National Science Foundation as an independent agency in the Federal Government and laid the basis for major promotion of education in scientific fields. The foundation is authorized and directed to develop and encourage the pursuit of a national policy for the promotion of basic research and education in the sciences.

In 1950, two series of laws were initiated to alleviate local problems of public education where, for example, federal establishment and staffing of large installations resulted in both withdrawo. of property from local taxation and a substantial increase in the size of the school-age population. Among the amendments are those in 1965 which provided for aid when a major disaster such as an earthquake or a flood devastates an area. 
On the 17th of May 1954, the United States Supreme Court handed down two historic opinions in the field of education. These held that the doctrine of separate but equal public educational facilities for different races is discriminatory and unconstitutional. The court recognized that many problems would need to be resolved in the transition from the existing practice to desegregation and full compliance with the decision. These decisions set in motion a general examination of regulations and practices and became the cornerstone in the construction of the first and only national standard with direct and immediate pertinence to education at every level and in all parts of the land, non-discrimination on the ground of race, color, or national origin in respect of any federally assisted program.

The Co-operative Research Act of 1954 authorized the use of federal funds to enable the United States Commissioner of Education to enter into contracts or jointly finance co-operative arrangements with universities and colleges and state educational agencies for the conduct of research, surveys and demonstrations in the field of education. As a matter of fact, the legislation opened the way for the regular support through the Office of Education for research and related activities conducted outside the office. Implementation of this law with its broad and flexible provisions helped to encourage inclusions of legislative provisions for co-operative research in a range of laws with specialized areas -- captioned films for the deaf, other media for educational purposes, language development, education of handicapped children, vocational education, and the like. 
Basically, progress under the various programs resulted in major expansion of the 1954 law by an amendment included in the Elementary and Secondary Education Act of 1965. Rightly, this act authorized funds for construction and operation of national and regional educational laboratories, for expansion of the program authorized in the $1954 \mathrm{law}$, and the training of the educational researchers. Provisions was also made for participation of private industry in research and development projects related to education.

The Library Services and Construction Act of 1964 was designed to assist in extending public library services wherever these were inadequate or lacking and to assist in the construction of facilities. The Medical Library Assistance Act of 1965 authorized help for medical libraries.

The National Defense Education Act of 1958 is a landmark in Federal legislation. It authorizes federal assistance: to help institutions of higher learning provide loan funds for needy students; to help the States and other parts of the country strengthen instruction in science, mathematics, modern foreign languages, and other critical subjects; to provide fellowships for the preparation of more and better qualified teachers at the higher-education level; to encourage guidance, counseling and testing, and the identification and encouragement of able students in elementary and secondary schools; to assist the establishment and maintenance of language and area centers; to heip research and experimentation for the more effective utilization of television, radio, motion pictures and related media for educational purposes; to assist institutions of higher learning 
conduct institutes for advanced studies for those in or preparing to enter professional assignments in elementary or secondary schools; to assist the States in improving and strengthening adequacy and reliability of educational statistics; to finance the National Science Foundation, which provides services leading to more effective dissemination of scientific information and undertakes programs to develop improved methods for making such information available.

In addition to the Vocational Education Act of 1963, the Government enacted the Health Professions Education Assistance Act of 1963, the Mental Retardation Facilities and Community Mental Health Centres Construction Act of 1963, and the Higher Education Facilities Act of 1963. The Government enacted these laws in helping to improve the qualifications of teachers and other school-related personnel, to extend research in different fields, to increase the availability of different types of programs such as those of adults and for education of the handicapped to expand physical facilities available, and, in general, to expand the opportunity for high-quality education. The Civil Rights of 1964 (PL 88-352) provides for nondiscrimination in federally assisted programs (Title VI) and for technical assistance grants, and training institutes to help communities prepare for school desegregation (Title IV). It is the most comprehensive survey ever made in the United States on educational opportunities in relation to the rights of individual to education regardless of their race, color, religion or national origin. This Act was in keeping with Supreme Court opinions of 1954 and 1955. 
This law also authorizes and directs each federal department and agency empowered to extend federal financial assistance and to issue rules, of general applicability which are consistent with achievement of the objectives of non-discrimination in federally assisted programs.

The Economic Opportunity Act of 1964 (PL 88-452) provides, through its education sections, for setting up a Job corps for unemployed youth, for community action programs to combat poverty, for work experience demonstration projects, and for the setting up of volunteers in Service to America (VISTA) modeled after the Peace Corps. These include preschool and high school projects in the community action program.

The Elementary and Secondary Education Act of 1965 (PL 89-10) and the Higher Education Act of 1965 and additions to each in 1966 are parts of the interrelated series making for cohesive federal assistance throughout the entire field of education. These recognize the needs of children of low-income families and the impact that concentrations of such families have on the ability of local education agencies to support adequate programs. They authorize funds for expanding and improving programs to help meet special educational needs of such educationally deprived children and youth, and also to help in the acquisition of the school-library resources, textbooks and other instructional materials.

The Higher Education Facilities Act of 1963 (PL 88-204) authorizes $\$ 1.2$ billion program of grants to public junior colleges and public technical institutes and to public and non-public colleges and universities. One of the programs aims at helping the said 
colleges and universities to strengthen their community service and continuing education programs and to use their resources in helping the people solve their community problems in such areas as housing property, government, recreation, employment, youth opportunities, transportation, health and land use. Another program seeks to encourage institutions of higher learning in the acquisition of books, periodicals, documents, tapes, records, audio-visual aids, and other materials for library purposes.

The National Technical Institute for the Deaf Act is aimed at opening up further educational opportunity for deaf secondaryschool graduates, while the Model Secondary School for the Deaf Act authorizes funds for the establishment and operation of such a model school to serve the District of Columbia and near-by states.

The War Orphans' Education Assistance Act of 1964 (PL 88-361) extends the application of the War Orphans' Education Assistance Act of 1956 to children of veterans who were totally or permanently disabled in the service.

The Juvenile Delinquency and Youth Offenses Control Act Amendments of 1964 (PL 88-368) extended to 1966 the Juvenile Delinquency and Youth Offenses Control of 1961. Also, it authorized a study of the relation of compulsory school attendance and child labor laws to delinquency, and provides an anti-juvenile delinquency project for Washington D. C.

The Nursing Training Act of 1964 (PL 88-581) provides funds for construction of nursing facilities, for training programs, and for loans to students. 
Finally, the National Sea Grant Colleges and Program Act of 1966 authorizes federal support for establishing, developing and operating sea grant colleges and programs of education, training and research in marine science, engineering, and related disciplines.

At the federal level, the President submits to the Congress the legislative proposals which the administration would like to see enacted in the field of education. These proposals, usually developed in the executive branch with the assistance of advisers from outside the Government, are introduced as bills by one or more members of the House of Representatives or the Senate or both. Ordinarily, the President issues executive orders pertinent to the field of education only when coordination and delegation of authority within the executive branch or international relations are involved.

Basically, federal regulations are issued by the heads of executive departments and agencies to provide procedural detail for carrying out federal laws such as those providing for the distribution of federal funds. Regulations are usually drafted by staff in the departments and agencies concerned and made available for review by advisory bodies and by those affected so that account may be taken of unforeseen difficulties.

A similar practice is followed in the fifty states and the Commonwealth of Puerto Rico, as well as the three national Territories. The governor usually obtains assistance from the appropriate department of education and advisory bodies and submits the proposals to the legislative body. Members of the legislature introduce these and other proposals and take the necessary action leading to enactment 
on signature by the governor. The Department of Education, in turn, always prepares implementing procedures including any necessary rules and regulations. Such rules and regulations of ten establish minimum standards and procedures for enforcement such as those of compulsory school attendance, the qualification of teachers and licensing of private schools and institutions of higher learning.

At the local level, the publically elected or appointed board of education, with the superintendent of schools as an ex-officio member, sets public-school policies in the framework of law and department of education rules and regulations. Among matters frequently within the province of the local jurisdiction are the preparation of the school budget, determination of the amount of local taxes to be raised for education, employment of teachers and other school personnel, and general overseeing of local public educational operations. 
CHAPTER IV

EDUCATION ADMINISTRATIVE STRUCTURE

\section{Responsibilities of the Federal Government}

The main concern of the Federal Government in the field of education is in encouragement, financial support, and leadership. Financial support of education by the Federal Government dates back to 1787 , increasing very slowly until after 1900 , but markedly since 1950. 16 The financial support function of Federal Government is at present used to focus education efforts on the problems that are of great national concern. The actual leadership of the Federal Government has been exercised primarily during the last half century.

The Office of Education in the U.S. Department of Health, Education and Welfare is the primary agency of the Federal Government functioning in the field of education. It has now three major responsibilities: educational research, educational services that cannot well be undertaken by a single state, and administration of grant programs. The grant program administration is now the major function of this Office and any regulations and standards connected with education which are determined by the Federal Government are related to the use of funds provided by the Federal Government through its program of categorical aids.

\section{6 world Survey of Education, Second Edition.}


In Nigeria, as in the U.S.A., the Federal Ministry of Education was until recently, responsible for education in the Federal Territory of Lagos. With the creation of new states 17 the Federal Territory of Lagos and its suburb became Lagos State and consequently the Federal Ministry of Education relinquished the administration of schools to the Lagos State. The Federal Military Government, as it has been called since the army coup d'etat of January 15, 1966, has no control over the regional Ministries, though it provides the secretariat for the Joint Consultative Committee which serves as a forum for liaison and coordination on matters of common interest. It acts on behalf of all the Ministries of Education in all international matters, in consultation with those Ministries. It prepares and publishes national educational statistics and maintains a national register of high-level manpower in training. The Bureau of External Aid for Education provides a clearing-house for requests from all the regions for external aid in the staff, equipment, finance and fellowships. It handles negotiations for aid and channels such aid to the various Ministries of Education.

The Federal Government opens and maintains Advanced Teachers' Training Colleges for the training of teachers to teach the lower sections of the secondary schools and the Teachers' Higher Elementary Training Colleges. It also opens and maintains Federal Secondary

17Decree No. 14 of 1967. 
Schools in all the States.

of considerable importance to educational legislation in Nigeria

is the Federal Government policy statement:

The Supreme Military Council has decided that the Federal Government should henceforth assume full responsibility for higher education throughout the country, with the proviso the status quo in respect of the existing universities should be maintained.

It also decided that education, other than higher education, should become the concurrent responsibility of both the Federal and the State Governments, and be transferred to the concurrent legislative 1 ist. 78

Responsibilities of the State Governments

The main structural features of the Nigerian ministries have a common pattern, based on a broad distinction between the professional aspects of their functions (generally grouped within an inspectorate), and other supporting services within the supporting system which are either combined within an administrative division or established in smaller and separate divisions, according to the specific duties they perform.

In all the Ministries, the inspectorate division deals principally with the control, supervision and inspection of the teaching service in schools and institutions of kinds up to the secondary level, with a view to maintaining and improving professional standards. In some cases, special services such as the organization of examinations, school

18 The Daily Times of 21 August 1972. 
broadcasting, special education (for the handicapped, etc.), rura] education and literacy and adult education are grouped within the professional division.

In other cases, these special services operate in separate units under a general administration division which, for example, has units for audio-visual aids, professional publications, Government scholarships and students' affairs, educational buildings, school libraries, educational planning (including educational statistics). In all Ministries, there are separate divisions responsible for finance and establishment matters. The finance section deals with the Ministry's accounts, including grants to voluntary-agency schools, while the establishment section deals with staff matters, the registry, stores, maintenance and other common services of purely administrative nature.

Indeed, the regional (state) Ministries of Education operate independently. They are responsible for the general directions of policy and planning, for the maintenance of the professional standards, and for the administration and financing of the education system within their respective regions (states).

Local authorities have power in all the regions (states) to establish and maintain schools in their respective areas of authority subject to the provisions of their respective regional education laws. Voluntary agencies, community groups and private proprietors can establish schools for primary and secondary education and teacher training, provided they obtain permission to do so from the regional Ministry of Education. 
Since 1970, some states have taken over schools from the voluntary agencies. The East-Central State inevitably took the lead by the promulgation of the Public Education Edict 1970 of the EastCentral State. 19 It was followed by the Mid-Western State with the Education Edict 1972 of the Mid-Western State.20 These were followed by South-Eastern and Rivers States. The number of schools existing in any area is subject to State Government control. Where there are too many schools competing for too few pupils, an appropriate number are filled to maximum enrollment level and the rest are closed down. The inspectorates in the regional Ministries of Education have permanent machinery for evaluation of the school system as far as professional standards in classroom work is concerned.

In many respects, the responsibilities of states in educational administration are the same as those of Nigerian states. In the United States, the responsibility for organizing and administering programs lies with the states, and they have the major share of the responsibility of financing the schools. Legally, the states could operate the schools directly, but all of them, except Hawaii, have created a third level of Government operation, the local education agency which is normally called the school district. It is on this that the states have placed the responsibility for the operation of the public elementary and secondary schools.

19Edict No. 2 of 1971.

20Edict No. 5 of 1973 Mid-Western Education Edict. 
Each state legislature, representative of the sovereign will of the people, has broad authority over education. In the exercise of this authority, the legislature customarily vests state and local school officials with the general control, administration and supervision of schools.

Since each of the fifty states is responsible for its own educational system, educational policies and practices differ. Despite their differences, state organization, especially for elementary and secondary education, have many elements in common.

Many states have created a board, commonly designated as the state board of education, to formulate state educational policies for the public school system, which consists primarily of the elementary and secondary levels. In addition, each state has a chief state school officer for the school system, who is usually called a commissioner of education or a superintendent of public instruction. This official and his staff make up the state department of education. As a rule, the formulation of educational policies for the public schools is a cooperative function, the chief state school officer reporting on school matters and conditions and make recommendations on educational policies for consideration and appropriate action by the state board of education.

The main functions of the state educational agencies may be classified under three major categories: leadership, regulatory and operational functions. The leadership functions are implemented through activities designed to stimulate and improve the operation of state and local school programs, without exercising legal authority, 
such as planning, research, advising, consulting, coordinating, and public relations. The regulatory functions are direct and consequences of state authority and responsibility for education, and the operational functions are a direct management and control of schools and colleges or educational programs. These functions are generally limited to those areas which local educational agencies find it impractical to administer.

The governing body of the local school-administrative district is termed "the Board of Education". Its functions cover a broad range of duties and responsibilities, including the development of annual school budget and, in most districts, determining the amount of total taxes for school support, employment of teachers, and other school personnel, providing and maintaining school buildings, purchase of equipment and supplies, and providing transportation for pupils living beyond a reasonable walking distance from school. The board functions also include enactment of rules and regulations, consistent with federal and state constitutional and statutory law and the rules and regulations of the state education agency governing the operation of the schools in the district.

Each state has an official (generally known as the state director of vocational education) with over-all responsibility for vocational education. His duties include both the administration of state programs and funds and supervision of programs in the local system.

\section{Finance}

In all Nigerian States by far the greater proportion of the funds 
required for education is provided by the State Governments from their own budgets. The amounts paid to grant-aided schools are supplemented with funds derived from school fees where these are chargeable as is the case in most of the states in the North and the South-Eastern State. Local authorities used to finance their own schools till 1974 when all schools became public schools. A small but no means insignificant measure of educational activity, particularly in the secondary commercial sector, is conducted in private fee-paying colleges. Although recognized officially, these have not been approved for Government grants. Education at university level, technical education at both secondary and post-secondary levels, and teacher training at all levels are financed by the Governments of the Federation from their own funds and with external financial aid. Since 1974, the Federal Government has taken over all the institutions except secondary schools as well as the primary schools. By September 1976 the Federal Government will finalize the taking over of the Godfathership of education from the State Governments.

With the introduction of universal free primary in all the states, the Governments of the Federation or the responsible localeducation authorities, as is in the North, have been responsible for providing funds for capital expenditure. However, the percentage of Government contribution varies from state to state. At the secondary level in all the states, except Lagos, where the Government gives a grant covering 100 percent of the capital expenditure, the voluntary agencies have to find the initial capital for buildings and equipment. Additional capital expenditure is partly refundable by the Government 
on certain conditions. The universities and other institutions of higher education also receive grants for capital expenditure from the various Governments of the Federation.

External aid, both international and bilateral, has been a vital source of finance for capital development. It has been used for establishing and running teachers' colleges at the advanced postsecondary level and for the expansion of primary education. The universities have also benefited greatly from external sources.

The Ministries of Finance provide public funds spent on education. The Ministries of Education prepare detailed estimates of expenditure and submit along with the estimates of other Ministries to the Ministries of Finance for clearance. When the draft estimates are approved by Parliament (the Federal Executive Council for the time being) at its annual budget session, the Ministries of Education are free to spend the amounts provided under their expenditure heads for the purposes specified. All payments, in fact, are made through the Treasury divisions of the Ministries of Finance, and are subject to their verification.

It must be vividly explained here, that the items of capital expenditure and the amounts voted each financial year for them represent successive stages of implementation of educational projects included in the national development plan. Details of costing and phasing are related as closely as practicable to the approved programme of implementation. All capital development projects are financed partly from funds set aside by the Governments from their own budgets and partly from loans or grants from external sources. For Government- 
owned projects, the financial provision covers all expenditures. In the Federal Territory of Lagos the Government gives a 100 percent grant for capital development in respect of even voluntary-agency schools. Federal funds are also granted to state Governments to aid educational development.

In the United States, like Nigeria, public elementary and secondary schools derive virtually all of their revenue from governmental sources. Unlike Nigeria which has some external aids, the United States has less than one-half of one percent of the total income from other sources, such as gifts and fees. Local governments used to contribute more than any other source, but in recent years the proportions from the federal and state governments have been increasing. In the school year 1965-66 it is estimated that about 53.8 percent of the revenue receipts of public schools came from local sources, 38.6 percent from state governments, and 7.6 percent from the federal government. The federal contribution is more than doubled between 1963-64 and 1965-66, rising from approximately $\$ 900$ million to $\$ 1,900$ million. Expenditure on education contributes the largest single item in the budget of the state and local governments.

Meanwhile, control of expenditure for education is exercised in part at the local level where local tax rates and expenditure budge $s$, within limitations imposed on the use of state and federal funds, are determined; in part at the state level where amounts of state funds for education and the conditions of expenditure are determined; and in part at federal level, where amounts of federal funds for education and the purposes and conditions of expenditure are determined. 
The uses of funds for education at the federal level are specifically fixed by Congress, the use of state funds for education are usually somewhat more broadly fixed by state legislatures, and at the local level school districts may use funds for any purpose which has been determined legally to be a part of the programme of the school.

In higher education the same general controls exist except that some sort of board of higher education or institutional board usually performs the functions carried on by the local school units for public elementary and secondary schools.

Specific items of capital expenditure for public schools are usually proposed by local boards of education or boards controlling institutions of higher education, but broad programmes of capital expenditure may be approved by the state legislatures or by Congress. School districts may finance capital expenditures from current revenue, usually in relatively small amounts, from bonds which sometimes must be approved by local voters, and from state and federal grants. Such support is usually not related to specific items such as land or buildings but to the total capital expenditure.

Central aid from the state or federal Government may be distributed on one or both of two bases. All education aids from the Federal Government are distributed on a categorical basis or for specific purpose. Some state aid is distributed on the same basis, often for school buildings, pupil transportation, textbooks, etc. However, a great deal of state aid for elementary and secondary schools is distributed as general aid and may be used by the local school 
district for many purposes, as long as it is for current expense.

In general, private institutions must be supported from private funds, such as fees, endowments, grants from foundations, gifts, etc., but those at higher levels are eligible for federal funds for building construction, both on a grant and on a loan basis. Pupils in private institutions are often eligible for benefits on the same basis as the pupils in public schools. Students in private institutions of higher education are eligible under the federal student-financial-aid programmes as students in public institutions. Pupils in private elementary and secondary schools are eligible often under state grant for such benefits as transportation and free textbooks while under federal programmes they have the same eligibility as pupils in public schools for such services as the use of school-library resources, textbooks, and other instructional materials and the benefits of special educational programmes for under-privileged children.

\section{School Buildings}

The designing and construction of buildings for Government-owned educational institutions in Nigeria are the responsibilities of the Ministries of Works (P.W.D.). Where such work cannot be carried out directly, contracts are awarded to provide building firms after competitive tender. Buildings owned by voluntary agencies and other proprietors are built by private contractors. These, too, are planned according to Ministries of Education specifications to ensure that they fulfill functional requirements to the highest standards of efficiency and hygiene. 
Selecting and purchasing sites, and planning, financing, contracting and constructing new school buildings are areas of educational administration in which a school district in the United States exercises a great deal of autonomy. The superintendent of schools, as the administrative head of the local school system, assisted by his staff, maintains school attendance records, projects school enrollments, and follows other techniques that will reveal the district's building needs five or more years in advance. When these data indicate a need for new facilities, the superintendent recommends to the board of education that necessary steps be taken.

Most but not all state departments of education require local school districts to submit for approval preliminary drawings and final plans and specifications for new construction, whether as additions to existing buildings or as complete new units. In addition, some states require approval of plans and specifications by the state fire marshal, and in some instances health authorities before construction contracts can be awarded. Supervision of construction, however, is generally a local function under the authority of the board of education.

Some federal funds are available for public-school construction in districts that experience an influx of school population as the result of federal installations. Federal control over schools in these districts is limited to financial audit to see that federal funds are spent only on approved projects and in accordance with building standards established by the state department of education having jurisdiction. 
Private elementary and secondary schools do not receive public funds for school construction, but in most states private-school buildings must meet state safety standards as required by applicable codes.

Equipment and Supplies

School supplies are usually purchased on authorization of the local board of education, by the superintendent of schools, the school business manager, or a purchasing agent. Whatever his title, this official usually confers with principals, teachers, librarians, custodians and maintenance workers. In most states there are statutes that stipulate conditions under which purchases must be made on the basis of competitive bids invited from suppliers.

A common practice among the states is that of using state funds, in some cases, with supplementary local funds, to purchase textbooks for all public-school children. Local districts sometimes furnish additional supplies such as pencils, paper, etc., to children without cost.

Most states have textbook commissions that operate under the direction of the state department of education to select textbooks for use in public schools. These commissions usually select several textbooks for each subject, and from this multiple list local school officials may choose the books to be used.

Many state departments of education operate centres that supply a variety of audio-visual materials (not equipment) to local school systems. In some instances these audio-visual centres provide instructional specialists who assist local school systems in setting up 
audio-visual programmes suitable to their needs.

Under the Nigerian system funds are made available in the budget estimates for headmasters and principals of Government schools and colleges to purchase books, materials, and equipment. The principals and senior staff of the schools such as heads of subject departments (including woodwork and metal-work) and games masters are responsible for the selection of supplies. Each school can purchase its requirements direct from suppliers or through the appropriate Ministry of Education. Advice is given by Ministries on textbooks, supplies and equipment and further guidance in such matters is given in the course of inspections.

Non-government grant-aided institutions receive grants to cover the cost, in part or whole, of the supplies they require. The choice and selection of such supplies is the responsibility of the authorities of the school. The Ministries of Education publish lists of recommended textbooks for use in primary schools, but as a general rule primary school headmasters or managers are completely free to choose the books they use. There is an exception to this in the Federal Territory of Lagos where textbooks for primary schools are prescribed and upplied by the education authority.

In some of the Ministries of Education, there are audio-visual units which serve all schools in the states. Educational broadcasts on radio and television are organized by these units or by a separate section of the Ministry specifically for school broadcasts. The audiovisual aids units produce and collect visual aid models which they show in special exhibitions for teachers. They also run in-service 
courses for teachers on the production and use of aids. 
CHAPTER V

OPERATION OF THE EDUCATIONAL SYSTEM

Inspection

In the Nigerian educational system, there is no distinction between the functions of inspectors, supervisors and administrators within the inspectorate. The staff are all professional. The preparation of inspection programmes and the collation of reports as well as the responsibility for supervision and administration, follow the order of rank and seniority within the inspectorate itself. General administrative duties in the Ministry of Education are not the concern of the staff of the inspectorate.

It must be remembered that Nigerian inspectors and supervisors are normally graduates with teaching qualifications, but in the primary level well-qualified non-graduate teachers of proven competence carry out inspections. 21

In the states, the chief inspectors of education, and in the Federal capital of Lagos, the Chief Federal Adviser of Education, who head the inspectorate are responsible for the overall organization, supervision and administration as well as the control of activities and the staff of inspectorate. They have the responsibility to execute matters related to the professional aspects of the operation

21 World Survey of Education, page 919, section 2 . 
and the development and expansion of the education system. They also have the ultimate responsibility for formulating policy proposals for the advice of permanent secretaries by whose decisions the questions of policy are finally determined at the official level. In addition to this, the Federal Chief Adviser in Lagos has the responsibility for liaison and co-ordination at the national level of policies and programmes concerning matters of common interests to all the states. Matters of common interest so far, are in connection with the training, grading, remuneration and conditions of service of teachers and with educational activities of an international character.

The deputy chief inspector in the Northern States or assistant chief inspector in the Western States, assists the chief inspector and acts for him in his absence. The exclusive responsibility of the chief inspector and his deputy is to deal with matters related to the international administration of the inspectorate and professional services, particularly with postings, promotions and discipline among professional officers. They are also responsible for duty assignments and the general regulation of the professional services. In Lagos, Mid-Western and Eastern States there is no grade of deputy chief inspector. Nevertheless, all the states have the posts in the grade immediately below. The posts are: staff inspectors in the former Western and Mid-Western States and principal education officer in Eastern States. In the Northern States they are called chief education officers. Also, the duties of these officers involve a good deal of administration as it relates to the international functioning of the inspectorate or professional division. "...it is 
necessary to see that these plans are carefully coordinated with other programmes of economic and social development, so that the educational system is not out of kilter with the other programmes in the development process. "22

The next significant category of members on the staff of the inspectorate is that known in Northern and Eastern States as inspectors or in the Western States as principal inspectors. Their duties are centred on the school inspections at the secondary level of the subjects in which they specialize individually. Normally, they also inspect and report on individual teachers. Furthermore, their duties include the checking and evaluating of syllabuses, schemes, and records of work, curricula and textbooks. Above all, they advise on teaching methods, educational experiments and research, school organization and management, school records and statistics, extracurricula activities and do demonstration teaching.

Normally, the inspectors or principal inspectors are based at and operate from headquarters. Field-inspecting staff working at the primary level, operate from the provincial education offices. The heads of these offices are called provincial inspectors, senior inspectors or senior assistant inspectors, according to the states.

School inspections are carried out by ad hoc inspection teams in the Federal Ministry of Education as there is no actual organized inspectorate as it is in the states.

${ }^{22}$ See Encyclopedia Britannica, Vol 6, page 316. 
In the United States, while educators more often than not act as both administrators and supervisors, the functions are substantially different. Principally, administrators are charged with operating the school system in accordance with policy decisions set by the local school board, various state agencies and boards, and the state legislature. The performance of advisory or consultative services is the responsibility of the supervisors. In the United States local school systems, supervisory services are concerned with improving curriculum and instructional programmes. Frequently, supervisors serve as staff personnel of the superintendent or assistant superintendent in charge of curriculum and instruction.

Like Nigeria, the United States Federal Government does not perform supervisory duties for public schools save in an ad hoc level. The United States Office of Education and other federal agencies, however, do render certain consultative and advisory services to local and state agencies on request. 23

The maintenance of supervisory services is the responsibility of State education agencies, although the services vary substantially from one state to another. On account of federal support to states, the supervisory services provided by the state agencies have been increased in recent years. Nowadays, the federal legislation allows the use of federal allocations for the hiring of supervisors to assist in administering federal programmes. This, normally, has given

23 World Survey of Education, page 1316, section 1. 
an impetus to the wider use of supervisors at the local level. Basically, the great majority of supervisory personnel in American Education is employed by local school system.

As the wider use of supervisory personnel increases, an increasing number of states are requiring school personnel such as administrators, principals, supervisors, speech and hearing therapists, audio-visual directors, librarians, psychologists, and guidance officers to hold special certificates appropriate to their respective positions. 24 It will be remembered that teacher education as an organized, officially recognized, and publicly supported enterprise began in the United States in the late 1830's. 25

The superintendent and principals perform all supervisory services and work directly with teachers in small school systems. In larger systems central-office supervisors are frequently employed as assistant superintendent, assuming a line authority between the superintendent and the principals. In other systems these centraloffice supervisors occupy a staff position and have no line authority over the principals.

In large systems, the assistant superintendent in charge of curriculum often has an elementary and secondary director of instruction on his staff. These officers direct and coordinate the activities of subject-area supervisors sometimes called helping-

${ }^{24}$ planning for Teaching by Robert $W$. Richey, pages 88-89.

$25 \mathrm{An}$ Introduction to Education in Modern America, by G. C. Lee, pp. $342-\overline{343 .}$ 
teachers or consultants. Smaller districts frequently participate in supervisory unions, or in intermediate districts designed to perform supervisory services for a number of sma11 districts. State agencies may also provide direct supervisory services to local school districts. The functions of supervisory staff normally include general supervision of instruction, most commonly for elementary schools only or for elementary and secondary schools combined. There are specialsubject supervisors in most major subject-matter fields, noticeably in the fields of reading, and language arts, mathematics, science and foreign languages. Included also are supervisors of kindergarten and early childhood Education. The current emphasis on education for children of pre-school age has increased provision of instructional supervisors in that area. Kindergarten, the first major institutional addition to the conventional elementary school, was imported from Germany where the movement was initiated by Friedrich Froebel, in 1885.26

Local and state level general and special-area supervisors are more often required to hold a master's degree in education or in a subject area. Supervisors are also required to complete a certain amount of training in supervision. Most of the supervisors are recruited from instructional and administrative personnel. The administration may recruit the most typical proficient teachers as supervisors. Principals serve in the dual capacity of administrators and instructional supervisors, in many local and state school systems.

26 See Education in Modern America, page 137-Lee, G.C. 
At the state level, supervisors are frequently recruited from the universities and supervisory staff of the local school systems.

\section{Administrative Standards}

The Nigerian Ministries of Education lay down regulations governing staffing ratios, the size of classrooms and laboratories, specifications for class-room furniture and equipment. These are contained in the appropriate education laws and regulations.

In the United States, generally, the states establish minimum standards in all areas of school operation. These include administration, curricula, instructional programmes and facilities and equipment. These minimum requirements must be made by individual schools and school districts in order to be accredited by the state. The laws and rules and regulations establishing standards vary substantially form state to state. There is no general compilation of state requirements.

The ratio of total instructional staff, including teachers, principals, and supervisors in 1966-67, to pupils was $4: 23$. When only class-room teachers were considered, the ratio was $1: 26.27$ These ratios vary tremendously from state to state and district to district according to state and $10 \mathrm{cal}$ requirements, wealth and financial effort.

27The National Education Association reports 1966-67. 
The minimum standards concerning class size and pupil-teacher ratio are generally fixed at state level through the state finance programme. It is the responsibility of the state to establish ratios by determining the size of the instructional units it will support. These units are generally conditioned by such variables as school size, urban-rural distribution and population density. Class size and pupil-teacher ratio standards are almost always set by the state authorities for accreditation purposes.

\section{Examining Bodies}

Nigerian Primary or First School Leaving Certificate Examinations are conducted by the Ministries of Education in the respective states. The West African Examinations Council conducts examinations for such states as Croo River State, Rivers State, Mid-Western and Lagos States. The School Certificate Examination that is taken at the end of the secondary school five-year course is conducted by the West African Examinations Council. Normally, this examining body serves the whole of English-speaking West Africa, save Liberia. The Council also conducts three papers in Teachers' Grade II Certificate Examination for the Ministries of Education. The papers are English language, Arithmetical Processes, and Principles of Education. It also sets and supervises General Certificate of Education (G.C.E.), both Ordinary and Advanced levels. The City and Gild of London, examines candidates for commercial examinations. All the Nigerian universities examine their students and award their own degrees. 
The syllabus for primary schools is prescribed by the Ministries of Education. The one for secondary schools is prepared by the west African Examinations Council. A number of vocational courses at the secondary level, such as secretarial and commercial courses, follow syllabuses prescribed by overseas examining bodies, such as City and Guild mentioned above. They are officially recognized by the state Governments. The courses lead to examinations conducted by those bodies. In the same way, non-degree courses in a wide range of professions, in engineering, commercial, accountancy, industrial, management and allied fields follow syllabuses prescribed by foreign professional bodies recognized by the Government. 28

In the United States, almost all testing of public elementary students is conducted by the local school district and schools. These children are generally tested periodically for achievement in various scholastic areas, for intelligence, social maturity and adjustment. Basically, there are no public national or state-wide tests for elementary students.

Generally, most testing of public secondary students is also conducted by the local school district and schools. They include achievement inventories, intelligence tests, social adjustment and personality inventorirs, and vocational preference tests. Institutions of higher learning require their would be students to take scholastic achievement tests. State-wide achievement exams are administered by some states. College-board examinations are also conducted by various

28world Survey of Education, Unesco, page 919. 
colleges and universities. There is no national public testing of elementary and secondary public-school pupils. Some states conduct testing, but in large scale testing is conducted by the school district and schools. Public colleges and universities test their students within their institutions. General achievement examinations of all students planning to enter the upper division of undergraduate school are required by some institutions. To graduate from any public institution generally depends on successful completion of the required course work within the student's major and minor areas of study and not a general examination administered by the institution, state, or federal Government. Generally, students seeking admission to graduate school must take a standard achievement examination such as the Graduate Record Examination, administered privately.

\section{Teaching Staff}

The laws in all states provide that teachers' registers be kept by Ministries of Education or education authorities in the form prescribed. The register has separate parts for each of the different recognized categories of teachers. To be enrolled in any part of the register a teacher must possess the qualifications appropriate thereto, as specified in the regulations. Apart from the possession of the requisite qualifications the only other condition for enrollment is that a person should be morally fit.

These are the categories of teachers: 1) Graduate teachers (with or without teaching qualifications); 2) Certificated teachers (of various grades); 3) Vocational teachers; 4) Uncertificated 
5) Vernacular teachers; 6) Probationary teachers. In addition to the diplomas awarded to graduates on successful completion of a period of post-graduate training, there are five grades of certificates for non-graduate teachers in categories (2) above.

A duly enrolled teacher may be employed directly by the manager or propriator or school board of a maintained or assisted school, or by an education authority. Grants-in-aid are payable in respect of such teachers up to the maximum number of teachers approved for such a school in accordance with the regulations. 29 The Government does not pay grants for teachers employed in excess of the approved quota. The Ministries of Education assess the salaries of teachers employed in grant-aided and maintained voluntary agency schools. No manager or proprietor may employ a teacher who is already employed on full-time duty at a maintained primary or assisted post-primary school to teach outside the recognized attendance periods. No teacher may take up such employment except in an approved adult education or literacy centres. Any teacher who leaves the employment of a school proprietor in breach of an undertaking given by him in consideration of his being trained or employed, or in violation of agreed conditions of termination, may not be employed in another school. After his name has been removed from the register of teachers, he may not teach in any institution. The rule binds during any period

\footnotetext{
${ }^{29}$ Education Ordinance. Gazette No. 29 of 20 th May, 1948.
} 
of suspension, also. 30

In institutions owned by local authorities or voluntary agencies the dismissal of teachers is subject to the control of the authorities concerned under rules of management or articles of Government in force in the schools.

Excluding Lagos, the education laws provide for the establishment of a teachers' disciplinary council in each state. The Minister of Education is authorized to appoint the members of council including the chairman in accordance with the provision of the law. The secretary should be a public officer who is not a member of the council. The teacher concerned should be given the opportunity to defend himself according to the laws and to furnish an explanation of his conduct before action is taken on the advice of the disciplinary council. In the Federal Territory of Lagos the Law empowers a school proprietor or a manager designated by him to appoint or dismiss teachers.

Concerning teacher education, Leonard J. Lewis has this to say, "the whole fabric of the educational system and the success of the policy is dependent upon there being a sufficient supply of skilled teachers at all levels."3l To maintain and keep good quality teachers, the salaries and the conditions of service of teachers are subject to negotiation from time to time, through the machinary of special

$30 \mathrm{~A}$ Bill for an Ordinance to Make Better Provision in Regard to Education in Nigeria, Government Printer, Lagos 1948.

31 prospect of Educational Policy in Nigeria, L. J. Lewis; Education and Politics in Nigeria pages 257-252. 
ad hoc negotiating bodies established by the Government. The committee consists of representatives of Government and local authorities, the voluntary agencies, and the Nigeria Union of Teachers. The revised salaries and conditions of service are put into the form of amendments to existing regulations and enacted by formal legislation. The teachers have terms and conditions of service which in all respects are identical with those of the civil service. The committee led by the Honourable Udorji was set up in 1974. It recommended very fabulous salaries and thought-provoking conditions of service for the teachers, for the first time in the history of teachers in Nigeria. This jesture has once and for all broken down the bridge of the exodus of teachers from teaching fields to civil service and merchantile work. It came into operation in 1975. The quality of teachers will now be preserved as Lt. Col. (Dr.) A. A. Ali, Federal Commissioner for Education in an address to the 42 nd Annual Conference of the Nigeria Union of Teachers in Kaduna stated, "The quality of our education will depend on the quality of the teachers in the country. 32

Retiring allowances and gratuities are payable to non-Government certificated teachers at the same rates now as against special rates for the last negotiation. Nowadays, non-Government teachers are entitled to be paid leave and leave transport allowances where applicable and special responsibility allowances to teachers holding posts of responsibility, such as headmasters, principals, special p. 8.

${ }^{32}$ Nigeria Newsletters, Consul General Office, San Francisco, 
science, and games' masters, senior tutors, and sectional heads. Principals, vice-principals, and headmasters are paid car allowances while other teachers who use their cars for official duties are paid transport mileage allowances. Lewis says, "Crucial to these and all the other plans for the expansion and development of education is the supply of money for the services."33 The structure of salary scales corresponds the official grading of teachers in a range from $\mathrm{N} 12,696$ 13,968 per annum for a graduate to $N 900-N 1,140$ for a grade III teacher. In the past the salaries and conditions of service of nonGovernment teachers, who contribute the main bulk of the nation's teaching force, were not as attractive as those of the civil service and commercial and industrial firms. Conditions have recently been improved and are the same as, or even better than, those existing in other fields of employment. Thus, it is becoming easier to recruit candidates on competitive terms to the teaching service, except in the field of science where industry continues to offer much more attractive terms to science graduates.

In terms of number there is no shortage of teachers in the primary schools, but there is a serious shortage of adequately trained teachers. In some states, noticeably in the Southern States, the situation is better than the others. For the Federation as a whole, the ratio of the number of untrained teachers to that of trained teachers is roughly $1: 3$. Basically, about four-fifths of the teachers

33Education and Politics in Nigeria-Leonard J. Lewis, page 252. 
are male. At the secondary level there is no shortage of teachers of arts subjects in any of the states except in the Northern States. There is a serious shortage of science and mathematic teachers in all states. The number of expatriate teachers continues to exceed that of the indigenous graduates in all the states except the Western States and to a lesser degree the Eastern States. The shortage of qualified teachers is particularly serious in the fiald of technical education where there are very few indigenous teachers with adequate professional training.

There are various in-service training programmes and short refresher courses all over the country for teachers of all categories. The Ministries of Education, the universities, the advanced teachers' training colleges and the Nigeria Union of Teachers have organized programmes of in-service training for teachers. It is in this that Hugh H. Smythe, in his "Educational Foundation of Nigerian Politicians" has this to say. "Responding to this continually growing desire of the population for more and better education, the government has strained its budget in an effort to provide more educational opportunities in every category."34 Under the scheme for Commonwealth Co-operation in Education, the Federal Government, in co-operation with the United Kingdom Government, runs annual vacation courses for teachers of all grades, conducted by experienced United Kingdom teachers at various centres in Nigeria.

The advanced teachers' training colleges, supported by UNESCO,

34Educational Foundation of Nigerian Politicians, H. H. Smythe. 
plan to develop their programmes of in-service training for grade II teachers preparing for grade I certificate. The UNESCO National Commission for Nigeria, in collaboration with the Ministries of Education and the university institutes of education, in planning a national seminar on the organization of in-service training for Ministry of Education inspectorate staff and the heads of teachertraining institutions in the Federation as further step towards the improvement of schemes.

Each Ministry of Education has its own school calendar. For primary and secondary schools, normally, the school year runs from January to December 2 with short vacation periods in April-May and August-September, and a long vacation December-January. Normally, there should be 13 weeks per term or 39 weeks per annum and 13 weeks' holidays in the year. There must not be less than $31 / 2$ hours and $41 / 2$ hours in infant classes and other classes respectively. The daily attendance period is divided into two, with 30 minutes break between them, counting each part as an attendance period. At least 360 attendance periods must be had by every maintained primary or assisted post-primary school.

The minimum number of teachers required in any school is as follows: 1) in every primary school, one teacher for every 40 pupils or part thereof on the register of the school. 2) In every postprimary school, one teacher for every 30 pupils on the register of the school. In some states a minimum teaching load of 26 class periods per week out of a 30-40 period week is prescribed. In primary schools, there is a teacher for each class who takes that class in all 
the subjects in the time-table. In secondary schools there are subject teachers each of whom specializes in one to three subjects which he/she may teach a number of grades or forms. 35

Last of all, the principals of colleges, headmasters or managers of schools, subject to the general provisions of the statutory regulations governing matters of administrative nature, can exercise a great deal of initiative and influence on the life and work of the school. On their judgement and decisions rests the scope and composition of the school curriculum. In it, also, rests the variety and arrangements of courses, the choice of subjects, textbooks, materials and aids, the selection, streaming and grading of the pupils, guidance and counseling, the interests, health and welfare of pupils and the organization of school life.

In the United States, teachers are certified by the states in which they teach through a certification commission or board either separate from or a part of central-state-education agency. Some states share certification authority with local districts and universities. Local school districts can set higher requirements for employment than state certification requirements, but it is the state generally that issues the teaching license.

A Bachelor's degree is the requirement of almost all states for beginning elementary and secondary teachers. All enforce at least the bachelor's degree for regular beginning high-school teachers' certificates. In some states, emergency or temporary certificates are

35Western Region Government Education Law, 1954, Ibadan 1955. 
issued, in addition to regular ones. These license a person to teach temporarily until a properly certified teacher can be employed or until the temporarily certified teacher meets the minimum requirements for a regular certificate. In addition to the above requirements for certification, a candidate will be required to the authorities with a minimum age limit, citizenship and sound health certificates. The requirement of some state is a pass in the National Teacher's Examination or the Graduate Record Examination. The vocational education teachers' requirements are somewhat specialized, on account of the nature of their work. Vocational agriculture and home economic teachers must be graduates of approved programmes such as land-grant colleges and universities. Teachers negotiate with or apply to local school boards for teaching contracts. Contracting with the local board means contracting with the state, because the board is the agent of the state. The contract, as a matter of fact, is subject to state laws, rules and regulations. A beginning teacher usually is given a contract which gives him a legal right to teach for one year only. 36 The teacher cannot be dismissed during the term of the contract except for "justifiable" cause. 37 The teacher has an obligation to employing officials, in return for the protection that the annual

36 World Survey of Education, "Educational Research by UNESCO Page 1317, Column 2.

${ }^{37}$ Planning for Teaching, Robert W. Richey, McGraw-Hi11, 1968 p. 275. 
contract provides. As Stinnett points out, "The truly ethical person takes great pride in strict observance of a written agreement or oral pledge."38 Twenty-five states have state-wide tenure laws. By tenure laws is meant, the continuing employment of teachers who, under its terms, have acquired permanent or tenure status, and require school boards to comply with prescribed procedural provisions of notice, statement of charges, and right to a hearing before a tenure teacher can be dismissed, or before a non-renewal of the teacher's contract of employment can be effective. Seven states have tenure laws that may be optional in some types of school districts. Six states have tenure only in certain districts, generally local tenure laws as opposed to the state-wide tenure law. This may be regarded as protective continuing contracts.

Facutally speaking, state laws vary considerably as to how long a teacher must work and how old he must be in order to qualify for retirement benefits. 39 Regardless of years of service, the retiring age is commonly 65 . Some states specify 60 years as the normal retirement age.

It is estimated that 50 to 60 percent of all instructional employees in public elementary and secondary schools are covered by social-security benefits.

38Stinnett, T. M., and Albert J. Huggett: Professional Problems of Teachers, The McMillan Company, New York, 1968, page 10.

39 world Survey of Education, page 1317, Section 2. 
The school board is the employing agency in nearly all school districts in the United States. The extent to which the local board consults its superintendent and staff as well as principals and teachers in the system of hiring its personnel varies from state to state, depending on the size of the district concerned. In the school districts, the appointment of principals has no standard procedure. There are some systems in which the superintendent recommends a principal for appointment. The board members accept or reject with little formal discussion. Others employ elaborate recruiting and selection procedures. In some districts the primary criterion for appointment of assistant head-teachers might be recommendations of the principal, while in others the superintendent or his staff take initiative. What is more, in some others, particularly in small districts, the school board takes an active role in the selection of assistant principals.

Nearly all the Governments of the Federation have changed to single-salary schedule.40 They have also, abandoned the salary schedule based on sex and dependents. Some schedules are based on "extra pay", "additive salaries", "off-schedule salaries", or "compensation for irregularities." 41

More often, the school boards have the authority to establish salary scales for teachers. In some cases, a committee comprised of

40This means that elementary, intermediate, and high-school teachers are all paid on the same schedule. or term.

4lpaying teachers for assignments beyond the regular school day 
board members, teachers, administrative staff and laymen is charged with recommending a particular salary scale to the board. In others, the superintendent and the board may establish a scale with little teacher or laymen participation. An arbitration board at the state level is constituted as the final authority to bargain or negotiate for the teachers.

The demand for teachers in the States will exceed the expected supply by 169,300 , provided the turnover and re-entry rates of qualified, experienced teachers approximate that of recent years. This shortage comprises 141,800 teachers at the elementary-school level and 27,500 at the high-school level.42 A U.S. Office of Education study found that salary was a contributing factor in teachers leaving the profession. The general trend existed for both men and women.

There is a dearth of professional people adequately qualified to perform the various functions and assume necessary responsibility in a viable, up-to-date vocational education programme.

About fifteen percent of those who completed their courses in institutions of higher learning were employed as instructional staff members in elementary, secondary schools and in higher education in 1965-66. This ratio only provides an approximate idea of that proportion of total eligible graduates who are retained by the system as instructional personnel.

42The National Education Association 1966 study on the teacher supply and demand in public schools. 
The social status of teachers in the United States may be determined by one or by combination of these indicators -- economic level, educational level, occupation of father, and images and stereotypes of teachers and teaching as an occupation. Some of the above indicators tend to lower the teachers' social status; others tend to raise it.

The fifth-year programme for liberal arts graduates has stimulated co-operation between public schools and teacher education institutions. It enables them to qualify for a teaching certificate on completing a one-year programme of teacher preparation. Tremendous impetus for inservice education has been supplied by institutes in subject-matter fields. The National Defense Education Act provides support for both summer and year-round institutes in mathematics, science, language and guidance.

Teachers are frequently required to participate in in-service programmes for certification purposes and by school board or administrative policies or regulations. This is a primary reason for the teachers'participation. What is more, the major reason for participation is the fact that such study can often be counted toward a higher academic degree or higher placement on the salary schedule with a concomitant salary increase.

The state law or regulation sets the minimum elementary school day. Children in primary grades spend five hours in school while 
children in the intermediate grades spend five and half hours in school.43 Because of huge enrollment increases, metropolitan areas have forced some elementary schools to organize double sessions or shifts. The school year is approximately 180 days in length.

The average public school teacher worked 47.3 hours a week. 44 About 43 percent of this time was utilized in duties other than classroom instruction.

The options in the area of curriculum vary from state to state. Some states have course outlines that must be followed, others have statutory requirements that a given course or courses be taught. What is more, others leave the matter of curriculum choice in the hands of the local school districts.

A considerable influence on the curricula of secondary schools is exercised by the regional accrediting bodies. Curricula must come up to a prescribed minimum standard and the freedom of teachers and principals to make decisions be curtailed, before the states which are responsible for accrediting schools can approve schools for accreditation. While certain state regulations limit the teachers' options of adopting school textbooks, they are offered a range of choices. They are, in addition, often involved in setting of standards or in selecting textbooks. There is often great freedom in the choice of supplementary books and materials.

431950 data which indicated the school year has been shortened. 44The National Education Association study of 1963. 
The state department of education, local administrators or committees composed of teachers and principals guide the teachers. The National Education Association may exert influence. Civic and patriotic organizations may influence the selection of content.

Some states regulate private schools by specifying programmes and standards, while others may have little or regulation. The greatest influence on private secondary schools and colleges is exercised by the various regional accrediting bodies.

\section{Education Planning}

Nigerian educational planning at the national level is the function of the Federal Ministry of Education, though the regional governments have unfettered scope for independent initiative and action in respect. Such over-all planning has resulted in fixing national targets for the expansion of primary, secondary, technical and higher education in relation to national manpower needs. Practically, it has resulted in the allocation of Federal funds to support regional development programmes within the framework of the national plan. Harbison has rightly insisted: "Nigeria's most urgent need in the near future is for expansion of intermediate education." 45

The Federal Chief Education Officer/Development co-ordinates planning and development activities through joint consultations in a

45Education and Politics, James 0'Connell, page 129. 
special planning committee composed of the heads of professional departments in charge of post-secondary, secondary, technical and primary education and teacher training. Included in the committee are the officers in charge of the sections responsible for statistics, the registrar of high-level manpower in training, the Bureau of External Aid for Education, the National Educational Research Council, the Conference on Curriculum Review. J. W. Hanson has this to say, "Success both in formulating and in implementing a sound plan will require a full participation of both the regional Governments and the teaching profession." 46

So far, some broad goals have been adopted by a11 the Governments of the Federation, since the publication of the Ashby Commission Report and the prior and subsequent interregional consultations on educational problems in 1960 . These were outlined by the Federal Government in Sessional Paper titled "Educational Development 196170.47 These broad goals include the preservation and fostering of the indigenous cultural heritage and the production of manpower which will enable Nigeria to take its place in a technological civilization. A basic goal of Nigerian educational development is the expansion of all types and levels of education. The goal set for Western (States) and Eastern State Primary education, has been the achievement

46Education in Nigeria Ikejiani-Hanson, page 57.

47Federal Government in Sessional Paper No. 3, of 1961. 
of free universal primary education by 1970. The goal set for Northern States, which were lagging behind the other states educationally, is to obtain an enrollment of not less than fifty percent of the children of primary school age. 48 The expansion in the post-primary education has been planned to take science and technological training into account.

The United States has a free rather than planned economy, so that there is no general national socio-economic plan. There is no real related national educational plan. Nevertheless, machinery and procedures for educational planning exist at every level of Government and also in the private and public secors of the economy. At the Federal level, for instance, there is extensive planning underlying the annual budget of the United States Government which reflects projected expenditures including those which the Federal Government plans for the promotion of education. Similar planning underlies the budgetmaking process in jurisdictions below the national level.

Massive Federal Government's commitments for international programmes in the field of education since The Second World War and Massive increases in federal financial and other assistance for education within the nation beginning in 1958 resulted in the President's Executive Order, which established the Federal Interagency Committee on Education. 49 This committee consists of the

48Northern Nigeria Education Laws 1962.

49president's Executive Order 11185 of 16 0ctober 1964. 
Assistant Secretary for Education as chairman, and representatives of some fifteen federal agencies as members. It considers projects in education with cross-agency lines (such as those in the manpower and research fields) and relates plans for federal assistance to general and long-term education needs throughout the nation.

The advisory council and committees mostly established under specific mandates in individual laws authorizing federal financial assistance programmes for education, assist the Secretary of Health, Education, and Welfare and the Commissioner of Education. Untold advisory councils and committees focus on federal education programmes which have implications for many fields. Congress also has a series of committees and councils concerned with federal planning to promote education. Chief among them are the Standing Committee on Education and Labor of the House of Representatives and the Committee on Labor and Public Welfare of the Senate and their respective subcommittees on education. Ad hoc bodies also play a major role in planning in the executive and legislative branches.

Machinery and procedures of educational planning within the various jurisdictions of the nation are the similar to those at federal level. Differences focus on content of the planning and on day-by-day involvement of broadly representative interests school personnel, parents, business and industry, civic associations, professional organizations and unions, religious bodies and governmental authorities. It is at jurisdictional levels immediately below federal that planning leads to enactment of 1 aw to control and regulate education. 
Quality of Education

Curriculum reform is everywhere a constant necessity for improving the quality of education. Pathetically, it is often the case that obsolete patterns have been imposed on subject people without the slightest regard to their inherent irrelevance to the social and cultural background. No attention is given to the economic and political aspirations of those people. One of the first essentials in the general process of decolonization has been the speedy reform and adoptation of the curricula and the content of the subjects taught in schools so that education may be made to grow out of the experience and the circumstances of local life and culture and to develop as a creative and generating force for the social, economic and political advancement of the people. George J. Mouly has this to say, "The teacher working with culturally disadvantaged needs to be particularly understanding as well as adept at relating the curriculum and his procedures to their needs and background." 50

Another important factor which can affect the quality of education is the methods and techniques employed in teaching practice. There is need therefore for continuing research in new methods and techniques of teaching, including the use of audio-visual aids. The new idea researched should be passed on to the teachers by means of special training courses, seminars and in-service training programmes. In Skinner's view, education must become more efficient to a degree

50psychology for Effective Teaching by George J. Mouly, page 417. 
that cannot be accomplished merely by our own building more schools and preparing more teachers; adequate systems of labor-saving capital equipment, that is teaching machines, must be developed. 51

The case for the revision of textbooks and the writing of the special textbooks and for reading materials for use in newly independent countries is the same as that for the reform of curricula. The aim should be to relate the factual content of such books, as far as possible, to what is familiar to the people in the circumstances of their life and in their own natural environment, in their history and in their folklore, their art and culture, their traditions and customs, their occupations and skills.

In the United States, provisions expressly related to quality of education first appeared in legislation enacted in the state of Massachusetts in 1837.52 As other state systems of education were established, provisions pertinent to quality in education were expressed in laws. Sometimes the identification was explicit and sometimes it came in the form of a higher minimum standard. The Federal Government has a long tradition of promoting higher standards of education and providing assistance for the fullest development of mental resources and technical skills through federal-state-local

51 Learning Theories for Teachers by Morris L. Bigge, page 144. 52Massachusetts Public Education Law of 1837 Horace Mann. 
partnerships and non-governmental effort. National conferences and committees on the subject, frequently under the President's sponsorship, have led to the introduction of legislation designed to improve the quality of education.

An entirely different approach to the securing of quality in education is illustrated by the accrediting agencies. 53 These bodies examine school curricula, library resources, qualifications of teaching staff, and the educational facilities themselves to determine whether or not they are of high enough standard to warrant accreditation of the institution with credits earned by those enrolled being readily transferable to other schools.

The accrediting function carried out by many of the departments of education promotes continuous efforts by elementary, secondary and higher schools in order that they may remain in the accredited list. Regional non-governmental accrediting agencies perform a similar role in raising standards, particularly at the secondary and higher education levels.

Curriculum

In Nigeria, the curriculum of the primary schools is prepared in each state by the Ministry of Education on the advice of curriculum committee of subject committees appointed by the Ministry. In the Federal Territory (now Lagos State) the local education conmittee is the body charged with responsibility for the nature and content of the

53An Introduction to Education in Modern American, G.G. Lee, p.261. 
syllabus to be followed in any type of school. 54

A National Curriculum Review Conference was recently established with special committees for particular subject areas. It is broadly representative of a cross-section of the national community, including Ministry of Education officials, representatives of voluntary agencies, teachers' organizations, and university institutes or departments of education. It is financed by the Federal Ministry of Education and has received a grant from UNESCO. 55

The secondary grammar school syllabus, however, is determined largely by the requirements of the West African Examinations Council which is the examining body responsible for the School Certificate Examination taken at the end of the secondary-school course.56 The council has expert committees and panels for the formations and review of the syllabus of secondary-school subjects for which it sets examination. These committees and panels are composed of experienced secondary-school teachers, university professors and professional staff of the Ministries of Education.

In the United States, the jurisdictions immediately below federal level have the authority to establish curricula. This authority is

54Federal Ministry of Education White Paper of 1966.

55 Statistics of Education 1966.

56The West African Examinations Council Regulations and Syllabus 1972 , p. 5 . 
exercised in the form of minimum standards either by the legislature or by the department of education or some other body acting under legislative authority. Latitude exists for differences to meet local needs results in wide variation in actual curricula in use. They vary from different systems in the jurisdiction, within the schools in the same system, and between the public and private schools. Usually there is broadly representative participation in planning to revamp curricula in order to encourage realistic programmes to meet needs at local level, within the higher jurisdiction, and in terms of the country as a whole. Often the departments of education call on assistance from outside the jurisdiction as well as within it. Teachers and school administrators play a major role in the total process, as well as parent-teacher groups, veterans' groups, religious groups, unions, and business and industrial interests. 57

There is no textbook on any subject which is in standard use throughout the co-ntry. Rather there are thousands of different ones. The authority to exercise control over textbooks used by the public and private schools throughout the country, rests with the fifty-five jurisdictions below federal level.

The multiple levels of responsibility for education place educational research and development in a very special position. They account in small measure for the way educational research has grown up in the United States and many of the special problems with which it

57 See Eclectic Philosophy of Education by John S. Brubacher, page 443 and The Child and His Curriculum by J. Murray Lee and Dorris May Lee, page 162. 
must deal.

Until very recently educational research and development had not received substantial funds at any level of education, local, state or federal. But in 1954 the Congress of the United States passed legislation which authorized the United States Office of Education to support research, surveys and demonstration in education.58 In 1958 the National Defense Act authorized research on the uses of the new media and on modern foreign languages. Subsequent federal legislation authorized research on vocational, handicapped children and youth, libraries and information.

The National Science Foundation supports curriculum development efforts for elementary, secondary and undergraduate education. The National Institute of Mental Health and the National Institute of Child Health and Human Development support extensive research learning and motivation. The Office of Economic Opportunity supports curriculum development and research and evaluation relating to such programmes as "Head Start" and Job Corps 59

Another recent development is the Educational Research Information (ERIC), an information storage and retrieval system for research and research-related information pertaining to education. Current plans call for even more attention to the curriculum and development tasks needed to reach the point where materials and

58 See the Co-operative Act of 1958.

59 The Structure of State Departments of Education, Bulletin, Miscellaneous No. 10, Office of Education USGPO (Wash., D.C., 1949). 
techniques used in instructional setting actually incorporate the validated theories through research.

This broad goal of educational processes can be broken into a number of parts. Research will try to develop better theories and understanding of learning and motivation as a base of improved and individualized instructional programmes. The researchers are of the opinion that curriculum development based on the systematic pursuit of multiple objectives to enhance local choice will be needed at a considerably expanded rate. The development of systems based on our knowledge of learning and integrated into larger instructional systems will assume a much more significant role than it has in the past. Particular attention, they contend, will be directed to uses of computer for instructional purposes. The computer will act as a mediator between teacher and learner, as a direct instructional device, and as a data-collection instrument for the study of human learning.

Further more, a much stronger emphasis will be placed on basic processes underlying learning. Support will increase for policy studies in education with a particular emphasis on developing projections for educational futures based on alternative assumptions and objectives. The researchers further hope that support will becrme available for model schools to try out advanced instructional designs. These would help to develop data on problems which need additional research and development data on the costs of establishing and operating entire instructional systems. 
CHAPTER VI

CONCLUSIONS, RECOMMENDATIONS AND IMPLICATIONS

Conclusions

In this paper, an attempt has been made to discuss historical backgrounds of Nigeria and the United States and its implications in the educational policies and the systems of the two nations. I have discovered that the Americans are successful in their educational policies and systems because the first thirteen states that emerged in 1776 were from England and had had the firsthand knowledge of educational policies and systems. The study revealed that three percent of the male colonists were highly influential university graduates.

Apart from that, the period they were under their colonial masters (1620-1776) was long enough to give them adequate preparations to cope with any situation. The period produced such people as Patrick Henry, Thomas Jefferson, George Washington, John Adams and a host of others to help them during the democratic revolution.

Today, the United States is two hundred years old. Her people have made the period an epoch of pushing ahead to be a political and educational power. Her educational achievements prompted them to fight for independent status, both for themselves and nations thereafter. 
Those who fought for Nigerian Independence soon after the World War II, were mostly American trained graduates, noticeably, Dr. Nnamdi Azikiwe, widely known as Zik of Africa. He is regarded as the "Father of Nigerian Independence and an advocate of Nigerian education. No wonder Dr. Okechukwu Ikejiani dedicated his book, Education in Nigeria to him thus, "To Right Honourable DR. NNAMDI AZIKIWE, M.A.M.SC., D. LITT., LL.D., P.C. for his Services to Nigerian Education." 60

Apart from producing intellectuals, America has given Nigeria standard universities as legacies (University of Nigeria, Nsukka and University of Benin, Benin City). Nigeria, a teenager for sixteen years, still needs help from her elder sister, two hundred years old.

The study has proved that America's educational advancement is too broad to be reached by Nigeria so easily without help from other sources. Vocational and technological education, which is the main path of American greatness, has not yet been developed to give Nigeria a better footing in the present scientific world. The Community Colleges make America a nation of surplus manpower. There is no community in Nigeria with such facility to hope for increased manpower for the young booming nation. The American primary and secondary schools are well equipped while their counterparts in Nigeria are poorly equipped on account of lack of funds. Visits to schools have shown that the democracy practiced in them influences the American pubiic life.

$60 \mathrm{Dr}$. 0. Ikejiani, Education in Nigeria, page XII. 
In trying to copy the American system of education, Nigeria has embarked upon a project that creates financial problems in spite of her buoyant economy in recent years. There has been an unprecedented expansion of education in Nigeria, in the past decades. For instance, in 1961 the total primary school enrollment stood at 2.8 million and in 1966, it reached 3.0 million. In 1968, in spite of the fact that the war-affected states of Eastern Nigeria closed down their primary schools, the enrollment rose to 3.1 million. The enroliment in secondary education with relatively leass expansion nationally, totalled 195,000 in 1962, 211,000 in 1966 and 215,000 in 1968. In the same period, noticeable expansion took place in teacher training colleges, particularly at the advanced teacher training college and univeristy levels in order to meet the increasing demands from primary and secondary schools. Vocational and technical school enrollment rose from 6,000 in 1962 to 10,000 in 1966 and 12,000 in 1968. The opening of four new additional universities highlighted the rapid development at the university sector, with 8,600 students in 1968 as against 3,600 in 1962. The Universal Primary Education (UPE) programme embarked upon by the Federal Government is aimed at enrolling an additional 2.3 million six-year-olds in September 1976.

According to the policies and objectives enunciated for education during the 1975-1980 period, special education institutes based on a thorough national census of the handicapped and their identified needs will be established throughout Nigeria. The Federal Ministry of Education has recently announced plans to have teachers trained in Nigeria and abroad in the care and training of the 
handicapped and maladjusted children. To prepare students wishing to enter Nigerian universities, four schools of arts and science have been built in Lagos, Mubi and Sokoto and three new ones are to be established in Ondo, Abuja and Aba.

The above trend of events has placed more emphasis on the role of education for national reconstruction and economic development. It is observed, that the education system has been conceived of and used, to some extent, as a means to help bring about the desired directions and rates of change in the social and economic development of the nation. It is also observed that with the rapid expansion of education services and facilities at all levels and the concern for quality education, public and private expenditures for education have risen considerably in Nigeria. There are indications that expenditures on education in the past few years have risen more rapidly than both the output of the economy and the overall public expenditures in other sectors of the national economy. There are reasons to believe the education costs will continue to rise because as the population increases, more children will have to be educated. Therefore additional facilities will eventually be required and the existing ones will have to be expanded and improved. There will be demand for increased educational services and programmes to match the national philosophy of education and stated objectives of educational outcomes.

There are two implications arising from the financial crisis depicted by the critics both within and without Nigeria. First, ability to cope with the present and future educational needs requires information about, and knowledge of different shifts that have occurred 
in financing education. Secondly, a recognition of such a crisis provides the need for a more systematic budgeting procedure for education within the total economic and social development of Nigeria. The core purpose of such planning and budgeting must be to help the nation to decide more rationally how much of its total revenue can be reasonably committed to education as against other equally important and pressing development national needs like industry, agriculture, housing, health, transportation, and communication.

The critics fail to remember that Rome was not built in a day. Let it be remembered also that it took Great Britain fourteen hundred years after the conquest of Boadicea to draft the Magna Carta. It took her several centuries more to pave the way for the English Revolution which established a constitutional democracy. Even the United States of America, as mentioned earlier in this research study, spent one hundred and fifty-six years, after the landing of the Pilgrim Fathers, in tutelage as a vessal of an alien colonial power As Judge T. M. Stewart once pointed out, "The United States was heir to generations of civilization and experience in government. Her builders were fresh from schools and universities of Europe. British brains and capital laid the foundation of the American commonwealth of nations. 61

61ZIK-A (Selection from the Speeches of Nnamdi Azikiwe, page 3 . 
If lasting greatness is to be achieved in education, as in the United States, rigidity and traditionalism will have to be overcome. This demands an open mind regarding the future and a flexible philosophy of life. Greatness in education does not depend upon physical resources, nor upon external structure; rather, it depends upon vision and dedication and enthusiasm so that human resources are explored and cherished. 62

To achieve its goals Nigerian educationists must rely still on the cooperations of and emulation for vision, dedication and enthusiasm of their counterparts in the United States in matters pertaining to education. Like Francois Marie Arouet Voltaire I say, "Nothing enfranchises like education. When once a nation begins to think, it is impossible to stop it." 63 The educationists should help the Federal Government in the current National Development Plan laid down recently in Decrees and Edicts.64

American institutions and corporations as well as individuals will continue their kindness in helping Nigerian educational programmes at all cost. The support might take the form of training

62 Road to Modern Education by Frederick Mayer.

63Ikejiani, Education in Nigeria, page XIII.

64West African Journal of Education, Vol. XVIII, No. 2., June 1974, pages 783-87. 
her personnel or sending more personnel to help the training at home. The importance Nigeria attaches to her educational system and the role of education in national development makes solution of financial and economic problems confronting the system a concern of the highest priority today. She will be tremendously appreciative to any individual or group who will help her in her more rational approach for financing the system which, by and large, becomes desirable. She needs also aid to get through a system of analytical approach to education by solving the problem of conflicting administrative, educational and financial plans which hurt the system.

With her own resources and external aid Nigeria can make appreciable progress for which she can look to the future with optimism. Through better distribution and utilization of the limited resources for education Nigeria can achieve a virile quality system in the required quantity to fulfill national goals and in the long run can follow the United States' footprints. 


\section{REFERENCES}

A Daily Times' Magazine Division Publication, Nigeria Year Book, 1973.

Abbott, Frank C., 1958 U.S. Government Policy and Higher Education.

Adamson, John William, Publisher and Printer, New York, 1905, reprinted 1971, Pioneers of Modern Education in Seventeenth Century.

Al-Sobhi, Mohammed, Teacher Education in Saudi Arabia. Unpublished Thesis, Portland State University, 1973.

Americana Encyclopedia, on Education Vol. 6., 1974.

Anderson, Barbara Swanson, A Comparison of Two Methods of Instruction in Office Skills: Classroom-Laboratory and Classroom-Laboratory with Co-Operative Work Experience. Unpublished thesis, Portland State University, 1973.

Bigge, Morris L., Harper and Row, Publishers, New York, 1971, Learning Theories for Teachers.

Brubacher, John S., Eclictic Philosophy of Education, Prentice-Hall

Inc., 1962.

Campbe11, William Giles, Form and Style in Thesis Writing, Boston, 1954.

Colling, Patricia, Helen Greenway Publication, 1973, July to June, 1974. Dissertation Abstracts.

Compton's Encyclopedia, F. E. Compton Company, William Benton, Vol. 7, Publisher, Chicago, 1973.

Corey, Stephen 14., Bureau of Publications, New 1958, Action Research to Improve School Practices.

Cowan, L. Gray, O'Connel, James, Scanlon, David G., New York, 1965. Education and Nation-Building in Africa.

Education Code-Eastern Nigeria Government Printing Press, 1965.

Education, Encyclopedia of, Vol., 3, Educational Co-operation, Chicago, 1976.

Education, West African Journal of, Vols., XVI-XVII, 1972-1973. 
Education, West African Journal of, Magazine, Vol., XVIII, No. 2, June, 1974.

Education West African Journal of, Vol. XVIII, October, 1974, No. 12 and XIX February, 1975 to July, 1976.

Educational Research, Vol., 15-16. National Foundation for Educational Research in England and Wales, London, 1972-1974.

Evans, John A., "Educational Management Information Systems: Progress and Prospectives." Social and Technical Implication for Education. Ed. Philip K. Piele, et al., Eugene, Oregon: Center for the Advanced Study of Educational Administration, University of Oregon, 1970, pages 246-333.

Federal Ministry of Information, Nigeria Handbook, Lagos, 1973.

Field Enterprises Educational Corporation, World Book Encyclopedia, Vo1. 6, Chicago, 1976.

Frasier, Joseph E., An Introduction to the Study of Education, Harper and Row Publishers, New York, 1965.

Golenpaul, Ann, Information Please Almanac and Book Facts, Atlas and Yearbook, New York, 1976.

Grolier Inc., The New Book of Knowledge, New York, 1968.

Hans, Nicholas, Comparative Education. A Study of Educational Factors and Traditions, London, 1958.

Hilliard, F. H., A Short History of Educatuion in British West Africa, Nelson's Education Handbooks, London, 1957.

International Encyclopedia, Grolier Inc., Vol., 6, New York, 1973.

Lee, Gordon C., An Introduction to Education in Modern America, Henry Holt and Company, New York, 1957.

Mouly, George J., Psychology for Effective Teaching, Holt, Rinehart and Winston, Inc., San Francisco 1960.

Niven, Sir Rex, Informations About Nigeria. Its People and Government. London-Nigeria, 1967.

Oregon Journal, The World Almanac and Book of Facts, New York, 1974.

Richey, Robert W., An Introduction to Education in America from Colony to World Power. McGraw-Hill Book Company, New York, $195 \overline{2}$. 
Sasnett, Martena, and Inex, Sepmeyer. Educational Systems and Policies. University of California Press, Los Angeles, 1965.

Unesco Paris 1071. World Survey of Education, Vol. 4, 1966, Vol. 5, 1971 .

United States History for High Schools. Teachers' Edition, Boyd C. Shafer and Co., River Forest, ITlinois.

Weiler, Hans, Education and Politics in Nigeria.

Wilson, John, Education and West African Culture. University of London Institute of Education, New York, 1963. 